A Scoping Review of Behavior Change Techniques Used to Promote Physical Activity among Women in Midlife

*Danielle Arigo, Ph.D., ${ }^{1,2}$ Kelly A. Romano, M.S., ${ }^{3}$ Kristen Pasko, M.A., ${ }^{1}$ Laura Travers, M.A., ${ }^{1}$ M. Cole Ainsworth, Ph.D., ${ }^{1}$ Daija A. Jackson, B.S., ${ }^{4}$ and Megan M. Brown, B.S. ${ }^{1}$

\author{
${ }^{1}$ Department of Psychology, Rowan University \\ ${ }^{2}$ Department of Family Medicine, Rowan School of Osteopathic Medicine \\ ${ }^{3}$ Department of Psychology, Old Dominion University \\ ${ }^{4}$ Department of Psychology, Chicago School of Professional Psychology
}

*Corresponding Author:

Danielle Arigo, Ph.D.

arigo@ rowan.edu

201 Mullica Hill Road

Robinson Hall 116G

Glassboro, NJ 08028

Phone: (856)256-4500 x53775

Fax: (856)256-4892 


\begin{abstract}
Women in midlife experience health risks that could be mitigated by regular physical activity and reduced sedentary time, but this population rarely achieves physical activity levels that would protect their health. As a result, many behavioral interventions are designed to promote physical activity in this population, which are purportedly guided by theoretical models of health behavior (change) and activate an associated set of behavior change techniques (BCTs). The efficacy and effectiveness of these interventions appear to be limited, however, raising questions about their design and adaptation for women in midlife. Several aspects of these interventions are currently unclear. Specifically, which women they target (i.e., how "midlife" and "sedentary" or "inactive" are defined), which theoretical models or behavior BCTs are used, and how BCTs are activated in such interventions. A synthesis of this information would be useful as an initial step toward improving physical activity interventions for this at-risk group, and thus, represented the goal of the present scoping review. Eligibility required publication in a peer-reviewed journal in English between 2000 and 2021, inclusion of only women in midlife who did not have any medical or other restrictions on their physical activity (e.g., cancer diagnosis), and free-living physical activity or sedentary behavior as the target outcome (with associated assessment). Of the 4,410 initial results, 51 articles met inclusion criteria, and these described 36 unique interventions. More than half of the articles (59\%) named an underlying theoretical model and interventions included an average of 3.76 identifiable BCTs (range 1-11). However, descriptions of many interventions were limited and did not provide enough detail to determine whether or how specific BCTs were activated. Interventions also used a wide range of inclusion criteria for age range and starting activity level, which has implications for targeting/tailoring and effectiveness, and many interventions focused on marginalized populations (e.g., women from
\end{abstract}


racial/ethnic minority backgrounds, those un- or under-insured). The present review identifies some strengths and highlights important limitations of existing literature, as well as key opportunities for advancing the design and potential utility of physical activity interventions for women in midlife.

Keywords: women's health, midlife, physical activity, behavior change techniques, behavioral intervention 


\section{A Scoping Review of Behavior Change Techniques \\ Used to Promote Physical Activity among Women in Midlife}

Physical inactivity is a key contributor to the development of cardiovascular disease (CVD; Blair, 2009), which remains the leading cause of death worldwide. The arrival of menopause in midlife confers additional CVD risk for women (Karvinen et al., 2019; Matthews et al., 2009); this change coincides with a decrease in physical activity, which widens the gender disparity in physical activity engagement that favors men throughout the lifespan (Caspersen et al., 2000; Troiano et al., 2008). Consequently, women experience increased CVD risk during midlife, and physical activity is a key method for reducing the development and progression of CVD in this population. Among women, physical activity is protective against specific CVD risk conditions such as metabolic syndrome, type 2 diabetes, stroke, and coronary heart disease (Gill \& Cooper, 2008; Hu et al., 2000; Lin et al., 2015) and also protects against cancer and osteopenia (Lynch et al., 2011; Moore et al., 2016; Watson et al., 2018).

A common approach to promoting physical activity is to deliver a behavioral intervention. This umbrella term is used to describe programs that employ individual or group discussions with a skilled facilitator to increase psychological skills that support physical activity engagement in daily life (e.g., using behavioral, cognitive, emotional, or social approaches). These interventions are delivered face-to-face, remotely (e.g., via phone), or using multiple modalities. Many researchers and clinicians suggest that women in midlife would benefit from behavioral interventions that are intentionally tailored to their unique needs. For example, in addition to the eventual onset of menopause and other physical changes, women in this developmental period experience changes in their caregiving and work demands, financial stability, and social networks that can affect their physical activity (Im, Stuifbergen, \& Walker, 
2010). As a result, many physical activity interventions ostensibly address these needs and recruit and enroll only this population.

Yet, there appears to be no single definition of "midlife," as experts acknowledge disagreement about the boundaries this period (Infurna et al., 2020). It may include any range between the ages of 30 and 69 years, and researchers may define "midlife" in a number of ways. Some studies appear to focus even more narrowly on subgroups of women in midlife, such as those from a particular racial or socioeconomic background (e.g., Koniak-Griffin et al., 2015). Despite their frequent participation in behavioral physical activity intervention trials open to adults (Cooke \& Jones, 2017; Waters et al., 2011) and the preponderance of interventions that are described as tailored for their needs, however, women in midlife consistently show low physical activity engagement (Lee \& Ory, 2013; National Center for Health Statistics, 2019). The characteristics of physical activity behavior change interventions that purportedly are tailored for this population warrant further investigation, to shed light on this discrepancy.

\section{Behavior Change Techniques in Health Behavior Interventions}

Behavioral or psychological theories often are used to guide the development of interventions to promote physical activity and other health behaviors. These theories suggest that specific experiences or constructs (e.g., motivation to engage in physical activity) are facilitators of or barriers to physical activity behavior; interventions then are designed to increase facilitating factors and decrease barriers by harnessing specific mechanisms of action associated with behavior change. The methods by which behavior change mechanisms are activated in interventions are called behavior change techniques, or BCTs (Abraham \& Michie, 2008; Michie et al., 2011; Michie et al., 2013). 
Notably, whereas BCTs provide insight regarding how interventions may promote adaptive health-related outcomes, theories provide a framework for understanding why health behaviors change post-treatment. For example, Social Cognitive Theory, which has commonly been used to guide physical activity promotion interventions among women (Flannery et al., 2019; Jenkins et al., 2017; Joseph et al., 2019; Perez et al., 2010), posits that learning and subsequent behavior change occurs as a function of reciprocal and dynamic interactions between individuals, their behavior, and their sociocultural environments (Bandura, 1998). A key component of this theory is that self-efficacy for changing physical activity (i.e., appraisal of one's own ability to make changes in this domain, Bandura, 1982) represents a powerful proximal determinant of behavior change. Consequently, interventions that are informed by this perspective frequently implement BCTs such as modeling the targeted behavior and reflecting on past successes. These BCTs are expected to account for the intrapersonal and contextual factors that are theorized to promote positive health outcomes (Flannery et al., 2019; Gilinsky et al., 2015; Jenkins et al., 2017) - specifically, increasing self-efficacy for engaging in physical activity as a mechanism to promote physical activity behavior change.

Although such theories frequently are used to inform the development of physical activity interventions and the selection of BCTs to be implemented, there is a considerable lack of consistency in the design and implementation of these treatments (Prestwich et al., 2014; Silva et al., 2014), as published descriptions of intervention trials do not always describe the specific features that activate BCTs. For example, several intervention descriptions indicate that participants self-monitor their physical activity behavior, but do not indicate how participants were taught to do this (e.g., using what methods, how often, and how any feedback offered should be used to inform physical activity decisions). Similarly, content often is delivered in 
groups "to facilitate social support," but descriptions do not provide details about how the group was used to activate social support (e.g., the content of discussions, specific activities, communication between group meetings). In interventions that are described as tailored for populations such as women in midlife, additional information about the BCTs included and the intervention features that engage them would help to synthesize existing knowledge and suggest next steps for more effective physical activity promotion in these groups.

\section{Aims of the Present Review}

Reviews and meta-analyses that have examined physical activity interventions among women have generally focused on intervention effectiveness (Flannery et al., 2019; Jenkins et al., 2017; Joseph et al., 2019; Perez et al., 2010), included women in a variety of developmental periods (e.g., only young and/or older adulthood, any age 18 or older; Anderson et al., 2014; Flannery et al., 2019; Jenkins et al., 2017; Joseph et al., 2019; Perez et al., 2010; Sherifali et al., 2017), or targeted women with specific experiences (e.g., pregnant or postpartum women; Flannery et al., 2019; Gilinsky et al., 2015; Sherifali et al., 2017). No existing review has focused on physical activity interventions that are described as tailored to the needs of women in midlife, the BCTs that are included in physical activity interventions for this group, or the theoretical rationale(s) guiding BCT selection.

To provide information specific to the design and content of physical activity interventions among women in midlife, the aims of the present review were to identify the definitions of midlife, the behavior change theories and associated BCTs that have been included in the design of physical activity programs for women in this age range, and any available details about their implementation. As an initial attempt to summarize this literature using broad research questions about intervention targets, we selected a scoping review approach, rather than 
a typical systematic review (which focuses on questions of intervention efficacy/effectiveness). Results may serve as an important initial step toward improving the understanding of how and why this population generally experiences modest outcomes following physical activity interventions and, in turn, guide recommendations to enhance intervention development.

\section{Methods}

This review followed the initial guidelines delineated by Arksey and O'Malley (2005) and the recent PRISMA Extension for Scoping Reviews (PRISMA-ScR; Tricco et al., 2018). Research questions and methods were registered with the Open Science Framework prior to data extraction (https://osf.io/g8tuc). The original procedure indicated that articles published by September 30, 2020 would be included; the search was updated in July 2021 to include all eligible articles published by June 30, 2021.

\section{Research Questions}

For the present review, the following research questions were explored:

1) Which women have been the focus of physical activity programs designed for women in midlife?

2) Which theories have guided the design of physical activity programs designed for women in midlife?

3) Which behavior change techniques are used in physical activity programs designed for women in midlife?

4) How are these behavior change techniques implemented in physical activity programs designed for women in midlife? 


\section{Article Identification}

Articles that met the following criteria were included in the present review: (1) available in English, (2) published between January 1, 2000 and June 30, 2021, (3) published in a peerreviewed journal, (4) described the outcomes of a behavioral intervention to promote free-living physical activity or exercise, or reduce free-living sedentary time, (5) a primary behavioral target and outcome was either self-reported or objectively assessed physical activity, exercise, or sedentary time, (6) the target population was women in midlife, and (7) the target population did not pose any physical activity restrictions or guidelines (e.g., cancer, high risk of falling, etc.). Articles were excluded from the review if they failed to meet these criteria; if the intervention aimed to improve immediate physiological outcomes (walking/running speed, gait, $\mathrm{VO}_{2} \max$ ), rather than to promote free-living physical activity/exercise or reduce free-living sedentary time; or if physical activity, exercise, or sedentary time outcomes were not measured with quantitative metrics.

We elected to include only studies published since 2000 to ensure that conclusions reflect the recent state of the literature in this area, which include increasing appreciation for the unique physical activity needs of women in midlife (Im et al., 2010) and various delivery modes that were not commonly used before 2000 (e.g., web-supported remote delivery; Arigo et al., 2019). To provide the most comprehensive overview of physical activity intervention techniques for women in midlife, we also elected to include interventions that focused on physical activity as one primary component of an intervention, but included other targets (e.g., weight loss, dietary change, stress management). We detected no meaningful differences in the use of BCTs between interventions focused exclusively on physical activity and those that had other target health outcomes. Consequently, all studies included in this review are considered together. 
The authors searched for relevant articles on PsycInfo, PubMed, Web of Science, and CINAHL databases using the search terms "women," "woman," "female," "midlife," "middle age," "middle adulthood," "physical activity," "exercise," "sedentary behavior," "active living," "aerobic exercise," "intervention," "treatment," "behavioral," or "NOT cancer." A total of 4,410 articles were returned from this search. After removal of 568 duplicates, 3,842 articles remained. Each article was evaluated by one author for this initial stage, to determine whether it met inclusion criteria based on screening the title and abstract. A total of 3563 articles were excluded, leaving 264 articles for full text screening by six of the authors (KR, KP, LT, MCA, DJ, MB). Two of these authors screened the full text of each article to ensure inter-rater agreement, and discrepancies were resolved by consensus with the first author (DA). During the full text screening, 213 articles were removed and 51 remained for the final stage of data extraction (see Figure 1).

\section{Data Extraction}

Data from the final set of 51 included articles were extracted by the authors. The following characteristics were extracted from each of the included articles; author(s) and year, journal published, sample size, sample characteristics, and definition of midlife (operationalized by inclusion criteria). Also extracted were data pertaining to the format and modality of intervention delivery, whether there was a control or comparison condition, and the reported theoretical grounding (if included).

Finally, BCTs and intervention features that were described as activating BCTs were extracted. An initial set of BCTs were selected for extraction based on the authors' familiarity with physical activity intervention research (specific to women in midlife and more broadly; Arigo et al., 2020a, 2020b; Arigo, 2015; Butryn et al., 2016). These BCTs included the following 
(with Michie et al.’s [2013] associated numeric codes): goal setting (proximal behavior [1.1] and/or distal outcome [1.3]), self-monitoring (proximal behavior [2.3] and/or distal outcome [2.4]), providing feedback (2.2), problem-solving and/or planning (1.4 and 1.2, respectively), social support (3.1-3.3), social comparison (6.2), and behavioral modeling (6.1). Additional BCTs described or alluded to in each article were also extracted, to provide a comprehensive overview of work in this area. These additional BCTs are grounded in behavioral and cognitive intervention traditions (e.g., stimulus control [12.3], reframing [13.2]). Each reviewer coded an average of 16 articles, with two reviewers per article. Comparisons between the two reviewers' coding of data extracted showed $80 \%$ agreement; discrepancies between reviewers were identified by DA and were resolved by a third coder.

\section{Results}

The 51 articles included for review described 38 distinct physical activity interventions for women in midlife; 13 of these articles (25\%) reported on secondary analyses from an existing intervention (see Table 1). Across primary and secondary outcome reports, 42 articles (82\%) described randomized, controlled trials with comparison conditions, and 9 articles (28\%) reported the results of single-arm pilot trials (including pre- to post-intervention change in physical activity and other outcomes). Sizes of samples included in analyses of intervention effects ranged from 18 to 645 women. Approximately equal proportions of articles indicated that the format of intervention delivery was in groups $(k=16,31 \%)$, individual meetings $(k=19$, $37 \%)$, or a mix of both $(k=16,31 \%)$. With respect to delivery modality, approximately half of included articles $(k=29,57 \%)$ described delivery face-to-face/in-person only, and $3(6 \%)$ described remote delivery (i.e., via mail or by telephone call). The remaining articles $(k=19$, 
$37 \%$ ) indicated delivery using a hybrid method (i.e. combination of face-to-face and remote modalities; see Table 1).

Across the articles included, "midlife" was defined in several different ways. This included use of various age ranges between 30 and 69 years old (e.g., 35-54, 40-65, 45-60; 4969) and menopause status (e.g., postmenopause; see Table 1). Less than half $(k=18,35 \%)$ indicated that eligibility required baseline physical activity to be below a certain threshold, and a total of 8 different thresholds were reported (e.g., <150 minutes of moderate-to-vigorous physical activity per week, no regular exercise). The majority of articles $(k=31,60 \%)$ also indicated that they recruited a specific subset of women in midlife, such as those who work in school systems (e.g., Gebretatyos et al., 2020), women with overweight or obesity (e.g., Kuller et al., 2012), or underserved groups (e.g., those below the poverty line; Samuel-Hodge et al., 2009).

Notably, $35 \%$ of the included articles $(k=18)$ indicated that interventions targeted women in midlife with marginalized or multiply marginalized identities. For example, $18 \%(k=$ 9) of the included articles noted that their programs recruited women in midlife who were primarily un- or under-insured, or otherwise had low socioeconomic statuses (Agomo et al., 2015; Hayashi et al., 2010; Keyserling et al., 2008; Khare et al., 2012; Kim et al., 2019; SamuelHodge et al., 2009, 2013; Scarinci et al., 2014; Thomas et al., 2016). An additional 27\% $(k=14)$ mainly or exclusively included women in midlife who identified with various racial or ethnic minority identities (Agomo et al., 2015; Fitzgibbon et al., 2005; Gaston et al., 2007; Gebretatyos et al., 2020; Koniak-Griffin et al., 2015; Khare et al., 2012; Samuel-Hodge et al., 2013; Scarinci et al., 2014; Sharpe et al., 2010; Thomas et al., 2016; Wilbur et al., 2008, 2016, 2017; Zenk et al., 2009). 
Nearly all of these articles $(33 \%, k=17)$ noted that their respective programs tailored their recruitment strategies and/or interventions to meet the needs of their targeted populations (Agomo et al., 2015; Fitzgibbon et al., 2005; Gaston et al., 2007; Hayashi et al., 2010;

Keyserling et al., 2008; Khare et al., 2012; Kim et al., 2019; Koniak-Griffin et al., 2015; SamuelHodge et al., 2009, 2013; Scarinci et al., 2014; Sharpe et al., 2010; Thomas et al., 2016; Wilbur et al., 2008, 2016, 2017; Zenk et al., 2009). For example, to meet the needs of women in midlife with low socioeconomic status, many of whom identified as Hispanic (80\%) and primarily spoke Spanish, the Be Wise program included intervention materials (e.g., handouts, a participant guide, etc.) that were written at a fourth-grade reading level in both English and Spanish, and included dietary interventions focused on foods that are common in the Hispanic culture and that could be purchased at grocery stores that accepted food stamps (Agomo et al., 2015). Likewise, in an intervention for women in midlife who identified as African American or Black and exhibited overweight or obese BMIs, culturally appropriate recruitment and intervention materials were developed to identify specific media (e.g., television and print materials), locations (e.g., churches), and core cultural values (e.g., promoting community cohesion, family/providing childcare, addressing religion/spiritual needs), to aptly recruit and engage this population (Fitzgibbon et al., 2005).

\section{Theoretical Underpinnings}

A total of 30 articles (59\%) indicated that the intervention described was based on an identifiable theoretical model (see Table 2). The development of physical activity promotion interventions included in the present review was guided most often by Social Cognitive Theory ( $k=13,25 \%$ of all included articles). For example, one study developed intervention modules with goal setting (BCT codes 1.1 and 1.3) and identification of rewards (many possible BCT 
codes), in line with this theory's focus on self-efficacy, perceived barriers and motivators, and perceived risks and benefits (Agomo et a., 2015). Five additional papers described self-efficacy as promoted via group discussions, either as an explicit discussion topic (Kim \& Kang, 2020; Shirazi et al., 2007; Wilbur et al., 2016) or enhancement by focusing the conversation on participants' successes (BCT code 15.3; Costanzo et al., 2006; Wilbur et al., 2005). Three articles referenced self-efficacy as a topic of take-home workbooks (Ehlers et al.. 2015; Napolitano et al., 2006) or videos (Nazai et al., 2020) provided to each participant, and 1 indicated the use of verbal persuasion from intervention facilitators or researchers during face-toface sessions (BCT code 15.1; Orti \& Donaghy, 2004). Additional articles described selfefficacy as promoted via BCTs such as goal setting (BCT codes 1.1 and 1.3) and social support (from group members and intervention facilitators; BCT codes 3.1-3.3; Anderson et al., 2006) or did not explain how self-efficacy was bolstered by the intervention (Gaston et al., 2007).

Another popular theory used to inform interventions was the Transtheoretical Model $(k=$ $8,16 \%)$. Aligned with this model, one study provided instructional sessions tailored to participants' stage of change, which included educational material, group discussions, and reflections on individuals' perception of susceptibility (BCT code unclear; Shirazi et al., 2007). Other theories used to guide intervention development included Cognitive Behavioral Theory $(k$ $=4,8 \%$ of all included articles); Interaction Model of Client Health Behavior $(k=3,6 \%)$; Person, Extended Family, Neighborhood Model (PEN; $k=2,5 \%)$; Self-Efficacy Model $(k=1$, 3\%); Health Promotion Model $(k=1,3 \%)$; Revised Health Belief Model $(k=1,3 \%)$; and Social Marketing Framework $(k=1,3 \%)$. Multiple studies $(k=8,16 \%)$ were described as integrating more than one theoretical or conceptual model to inform the design of their experimental interventions (see Table 2). 
In line with several of these theories, 9 articles (17\%) reported that interventions focused on increasing motivation for physical activity. Many did not describe the specific BCT intended to increase motivation. For example, five articles indicated that motivation was a topic of discussions in group, individual interactions, or workshops (Butryn et al., 2016; Fitzgibbon et al., 2005; Kim \& Kang, 2020; Wilbur et al., 2016; Zenk et al., 2009); 4 articles referenced providing motivational messages outside of live interactions, via mail or email (Sharpe et al., 2010), telephone (Wilbur et al., 2017), text message (Kim et al., 2019), or videotape (Keyserling et al., 2008). None of these articles described or provided examples of the content of motivational messages, though one linked to an external, supplementary resource that did include examples (Sharpe et al., 2010).

Notably, several articles $(k=21,41 \%)$ did not indicate how theories or conceptual models were used to inform either the design of their interventions or the selection of BCTs. Some articles that claimed that an intervention was informed by specific theory appeared to lack sufficient information about how their intervention was informed by that theory (Low et al., 2015) or contained intervention descriptions in separate protocol articles (Napolitano et al., 2006; see Availability of Additional Information, below).

\section{Goal Setting (BCT Codes 1.1 and 1.3)}

Goal setting was reported as included in $49 \%$ of the articles meeting the present inclusion criteria $(k=25$; see Table 2). Approximately half of these articles $(k=13)$ provided very brief descriptions that "goal setting" served as a topic of discussion during group sessions (Carels et al., 2004; Fitzgibbon et al., 2005; Gaston et al., 2007; Scarinci et al., 2014), individual consultations with study personnel (Anderson et al., 2006; Hayashi et al., 2010; Koniak-Griffin et al., 2015; Long et al., 2013; Low et al., 2015; Wilbur et al., 2008), or via print or web-based 
study materials (Napolitano et al., 2006; Orti \& Donaghy, 2004; Sharpe et al., 2010), but did not provide specifics on the nature of goal-setting discussions or materials. In contrast, 12 articles provided more specific details on how goal setting was incorporated (Agomo et al., 2015; Butryn et al., 2016; Costanzo et al., 2006; Keyserling et al., 2008; McGuire et al., 2019; Nazari et al., 2020; Peterson et al., 2005; Samuel-Hodge et al., 2009, 2013; Shariati et al., 2020; Wilbur et al., 2016, 2017), and there was considerable variability in how goal setting was implemented across these articles.

For example, 3 articles described helping participants learn how to set specific behavioral goals that had clear parameters (BCT code 1.1). Two involved individual consultations with study personnel who provided support for developing SMART physical activity goals (Specific, Measurable, Achievable, Relevant, and Time-bound; Costanzo et al., 2006; McGuire et al., 2019). The third article indicated that participants were led to set 2-3 physical activity goals by their intervention facilitators during individual sessions, with follow-up and goal re-setting as these sessions progressed (Keyserling et al., 2008). An additional 2 articles used a multi-faceted approach to goal setting, wherein participants were asked to set and reset goals using more than one format or modality. For example, 1 article indicated that goal setting occurred in both group discussions and individual telephone calls with health advisors between group sessions (Keyserling et al., 2008). The other described goal-setting discussions in face-to-face groups as well as via digital group message boards on the Fitbit platform (Butryn et al., 2016).

\section{Self-Monitoring (BCT Codes 2.3 and 2.4)}

Self-monitoring was incorporated in 26 articles (51\%), using a variety of methods (see Table 2). For example, 19 articles indicated that participants tracked their physical activity behavior (BCT code 2.3) in paper and pencil logs, with data from pedometers (Conroy et al., 
2015; Keyserling et al., 2008; Koniak-Griffin et al., 2015; Ribeiro et al., 2014; Sharpe et al., 2010), accelerometers (Carels et al., 2004), physiological data (e.g., heart rate, rate of perceived exertion during physical activity; Asbury et al., 2006; Orti \& Donaghy, 2004), and/or self-reports (e.g., total minutes of physical activity per day; Anderson et al., 2006; Carels et al., 2004;

Costanzo et al., 2006; Hollis et al., 2015; Ludman et al., 2009; Samuel-Hodge et al., 2009, 2013; Sharpe et al., 2010; Simkin-Silverman et al., 2003; Wilbur et al., 2001, 2005, 2008; Zenk et al., 2009).

Similarly, 5 articles described logging physical activity behavior (BCT code 2.3) in webbased platforms, based on data from pedometers (Ehlers et al., 2015), physiological measures (e.g., heart rate during physical activity from heart rate monitors; Wilbur et al., 2001, 2005, 2008), or self-reports (Cussler et al., 2008). One article indicated that participants used commercially available wearable sensors (i.e., Fitbit) to self-monitor their physical activity, and their physical activity totals were available in real time via the device and associated web and mobile platforms (Butryn et al., 2016). In other studies $(k=3)$, data from pedometers (Kim et al., 2019) or accelerometers (Wilbur et al., 2016, 2017) were regularly reported by participants to (automated) telephone response systems for self-monitoring purposes. A final article noted that self-monitoring was discussed in group sessions (Fitzgibbon et al., 2005), without specifying what these discussions entailed or which self-monitoring method was used.

\section{Providing Feedback (BCT Code 2.2)}

Fifteen articles (29\%) described interventions that provided participants with feedback on their engagement in physical activity. Most of these included only brief descriptions indicating that feedback was provided by research staff or intervention leaders ( $k=9$; Butryn et al., 2016; Keyserling et al., 2008; Mirzaei et al., 2021; Peterson et al., 2005; Samuel-Hodge et al., 2009; 
Scarinci et al., 2014; Shirazi et al., 2007; Simkin-Silverman et al., 2003; Wilbur et al., 2005)

and/or web-based automatic response systems ( $k=4$; Butryn et al., 2016; Cussler et al., 2008;

Ehlers et al., 2015; Wilbur et al., 2005). This BCT was described as providing participants with feedback on their current level of physical activity or the extent to which they attained their physical activity goals, without additional detail (including how often participants received feedback).

As exceptions, 4 articles provided more specific information on how and what types of feedback was provided during their interventions. In a print-based physical activity promotion intervention, participants were asked to complete a comprehensive questionnaire at 4 points during the intervention (i.e., at baseline and months 1, 3, and 6; Napolitano et al., 2006). Data from these questionnaires were used to generate individually tailored feedback reports that were mailed to participants, and targeted factors such as self-efficacy, barriers, benefits, social support, and goal setting related to physical activity. In addition, participants in a 4-session intervention were provided with feedback on their physiological responses to a supervised physical activity session (i.e., achieving between $60-85 \%$ of their maximal heart rates during physical activity, rate of perceived exertion; Orti \& Donaghy, 2004).

Other articles reported that their interventions provided feedback via both research staff/ intervention leaders and use of reports generated from automatic response systems. For example, participants received supportive feedback tailored to their current stage of change for increasing physical activity, compiled from self-monitoring data that participants entered into an automated telephone system and delivered by study personnel (Wilbur et al., 2008). Similarly, phone calls were used to provide feedback from an interventionist regarding step counts that participants reported to an automated telephone system (Wilbur et al., 2016). This feedback incorporated use 
of motivational interviewing techniques and was only provided after the interventionist and participant discussed the latter's progress in attaining their physical activity goals.

Problem-Solving and Planning (BCT Codes 1.4 and 1.2)

Thirteen articles (25\%) indicated that problem-solving skills were taught in the intervention (BCT code 1.4); 12 used group or individual discussion time to cover these topics (Keyserling et al., 2008; Koniak-Griffin, 2015; Long et al., 2013; Low et al., 2015; Ludman et al., 2010; Riberio et al., 2014; Samuel-Hodge et al., 2009; Wilbur et al., 2001; 2005; 2008; 2016, 2017), whereas 3 used print or emailed materials (alone or in conjunction with discussions; Long et al., 2013; Sharpe et al., 2010; Wilbur et al., 2008). The specific problem-solving skills were not described, with the exception of limited details provided by Scarinci et al., (2014; i.e., problem-solving "steps" were taught and problem-solving "ability" was evaluated). Similarly, 11 articles referenced the use of planning and/or intention formation with respect to physical activity behavior (BCT code 1.2), using group or individual intervention time to set a weekly schedule for activity (date/time/location; Agomo et al., 2015; Anderson et al., 2006; Butryn et al., 2016; Costanzo et al., 2006; Ehlers et al., 2015; Fitzgibbon et al., 2005; Keyserling et al., 2008; McGuire et al., 2019; Wilbur et al. 2005; Zenk et al., 2009) or being guided through the process with a video (Nazari et al., 2020).

\section{Social Support (BCT Codes 3.1-3.3)}

Social support was reported as an included BCT in 23 studies (45\%; see Table 2). Of these, 17 studies provided opportunities for or reviewed tips on obtaining support in person or in online group activities. To achieve this, 10 of the articles that referenced social support used group sessions, 3 articles used partner/group walks, and 2 used online community message boards. For example, one article described a focus on participants eliciting social support from 
family and friends by engaging in role plays during group discussion (Costanzo et al., 2006). Of the articles that described incorporating social support, 10 facilitated support via individual tailored sessions, psychoeducational resources, and materials on eliciting support for participants or their supporters to utilize independently (i.e., e-book, pamphlet, intervention staff feedback). For instance, multiple studies used individual coaching via phone or in-person sessions from study staff tailored to participant needs (e.g., Zenk et al., 2009; Wilbur et al., 2005; KoniakGriffin 2015). Articles that referenced social support as a BCT were approximately evenly split between those facilitating support from intervention leaders and members $(k=9,52 \%)$, and those providing discussion and tips for participants to elicit support from family and friends $(k=$ 8, 48\%). Importantly, several studies claimed to use social support but either did not meet BCT criteria (i.e., "prompting the person to plan how to elicit support from other people to help him/her achieve their target behavior/outcome;" Michie et al., 2011) or provided insufficient detail to discern whether criteria were met, and many descriptions lacked information about how social support was facilitated.

\section{Social Comparison (BCT Code 6.2)}

Only 2 articles (5\%) explicitly referenced social comparisons, or self-evaluations relative to others (Festinger, 1954). Peterson and colleagues (2005) indicated that their intervention was based on an extension of Social Comparison Theory, which identified comparison as underlying the effects of social support (Wills, 1985). However, the BCTs described were distinct aspects of social support (e.g., instrumental vs. emotional support; BCT codes 3.2 and 3.3, respectively), activated via group discussions and workbook activities. In contrast, Butryn and colleagues (2016) differentiated social comparison processes from those of social support, and engaged comparison as a BCT via data sharing. Specifically, this intervention used wearable physical 
activity monitors connected to a digital platform and an associated leaderboard, which ranked participants' physical activity behavior (e.g., steps per day) from most to least. All participants had access to this feature, which updated physical activity rankings in real time to facilitate physical activity-based social comparisons. One additional article (Nazari et al., 2020) indicated the use of a video testimonial from a woman in midlife who had lost $17 \mathrm{~kg}$ of her weight by increasing physical activity, though this was not specified as intended to activate social comparison processes.

\section{Behavioral Modeling (BCT Code 6.1)}

Thirteen articles (25\%) described the use of behavioral modeling as a BCT. Modeling was provided through live demonstrations of activities during group sessions (e.g., Fitzgibbon et al., 2005; Keyserling et al., 2008; Koniak-Griffin , 2015; Samuel-Hodge et al., 2009; 2013), via video demonstrations of activities (e.g., Nazari et al., 2020; Wilbur et al., 2008; 2016), or both (e.g., Costanzo et al., 2006). Another approach reported was to have facilitators hand out photographic illustrations of activities during intervention sessions (McGuire et al., 2019). Models were intervention facilitators, peers who were already successful with physical activity, or professionals (e.g., athletes, coaches). Though in many cases, the model was not specified (e.g., Gaston et al., 2007; Wilbur et al., 2017).

\section{Other BCTs: Skills Rooted in Behavioral and/or Cognitive Therapy}

Additional BCTs described in classic behavioral terms included stimulus control (BCT code 12.3; $k=3$; Butryn et al., 2016; Fitzgibbon et al., 2005; Shirazi et al., 2007) and reinforcement/reward management (BCT codes 10.2, 10.3, 10.4, 10.9, and 14.10; $k=4$; Agomo et al., 2015; Fitzgibbon et al., 2005; Orti \& Donaghy, 2004; Shirazi et al., 2007; see Table 2). These were either topics of intervention discussions or included as content in take-home 
workbooks. Of note, 4 articles indicated that incentives (BCT code 10.1) were used by program staff to reinforce goal attainment and enhance self-esteem (e.g., Agomo et al., 2015; Peterson et al., 2005). For example, participants in 2 interventions could earn items such as food storage containers, aprons, exercise videos, cookbooks, stick blenders, and pedometers for meeting their weekly physical activity goals (Samuel-Hodge et al., 2009; Samuel-Hodge et al., 2013). Other cognitively oriented BCTs that appeared in intervention descriptions included "self-evaluation" and setting realistic expectations (possible BCT code 15.4; Wilbur et al., 2016), cognitive restructuring (possible BCT code 13.2; Carels et al., 2004), and "cognitive-behavioral strategies" (unspecified; Thomas et al., 2016).

\section{Summary and Reported Availability of Additional Information}

Across all articles, the average number of identifiable BCTs reported as included in each intervention was $3.76(S D=2.51)$, with a range of 1 to 11 . Of note, 20 articles referenced outside sources as containing relevant details about intervention BCTs and their implementation (i.e., sources not included in the present review). Specifically, 10 articles referenced a protocol paper (1 that was under review at the time and appears to be unpublished), 2 referenced a website containing the intervention manual, and 9 referenced a previously published empirical paper that did not meet criteria for inclusion in this review. Thus, accessing critical details about the design and delivery of physical activity interventions for women in midlife required searching elsewhere for $40 \%$ of the articles included in this review.

\section{Discussion}

The past 20 years have seen considerable interest in using behavioral interventions to promote physical activity among women in midlife, with emphasis on physical activity as a method of primary or secondary prevention of health problems associated with conditions such 
as cardiovascular disease, cancer, and osteopenia. Specifically, the present review identified 51 articles published between 2000 and 2021 that report on findings from such interventions, which describe 38 unique intervention programs. The majority of these programs are delivered face-toface and use a group format, though subsets incorporate intervention delivery via telephone and individual discussions with treatment staff. Very few that primarily use live interactions with professional facilitators have added components delivered via mobile technology such as smartphones or tablets, and only 2 incorporated internet discussion boards to extend intervention contact between group sessions (Butryn et al., 2016; Ehlers et al., 2015). This represents a particular area of opportunity for future intervention adaptations, as digital components are both feasible and acceptable among women in midlife (Im et al., 2012; Joseph et al. 2021) and can extend content from intervention sessions to daily life.

One notable strength of existing research in this area is the representation of multiply marginalized women in midlife, such as those who identified as Black/African American, Hispanic/Latina, exhibited low socioeconomic status, were un- or under-insured, had higher body weights, and/or resided in rural areas (e.g., Agomo et al., 2015; Fitzgibbon et al., 2005; Gaston et al., 2007; Hayashi et al., 2010; Khare et al., 2012; Keyserling et al., 2008; KoniakGriffin et al., 2015). Many studies also tailored their recruitment procedures (e.g., held meetings at local and easily accessible community centers) and intervention components (e.g., intervention leaders who were part of participants' local communities, ensured that written handouts contained information at a reading level that was appropriate for study participants; e.g., Gaston et al., 2007; Koniak-Griffin et al., 2015; Samuel-Hodge et al., 2009; Thomas et al., 2016) to meet the needs of these populations. Such efforts are valuable for engaging subgroups of women in midlife who may be at risk for suboptimal intervention engagement, as well as at risk for 
insufficient physical activity and poor health outcomes related to their multiply marginalized statuses (Tovar et al., 2018; White et al., 2020). These programs warrant continued evaluation and implementation to address persistent health disparities.

\section{BCTs Included in Physical Activity Interventions for Women in Midlife}

In line with taxonomies described by Michie and colleagues (Abraham \& Michie, 2008;

Michie et al., 2011; Michie et al., 2013), descriptions of the physical activity interventions that were included in the present review indicated intervention BCTs that targeted a variety of mechanisms of action. Most popular among these (included in approximately $50 \%$ of the identified articles) were self-monitoring and goal setting. Goal setting appeared to include both proximal behavior and distal outcomes (BCT codes, 1.3 and 1.1, respectively), though the former was much more common; self-monitoring appeared to focus on behavior (2.1), rather than outcomes (2.2), though this was not always clear from the description. Both self-monitoring and goal setting have been associated with positive changes in physical activity and related behavioral health outcomes across populations (Berry et al., 2021; Epton et al., 2017). Notably, these BCTs were described with some detail in several articles (e.g., described how and the methods that were used to incorporate and activate these BCTs), which is useful for other researchers to maintain consistency, determine replicability, and advance science in this area.

In contrast, although promoting social support was also well-represented in included articles (referenced in approximately 50\%), there were few details regarding how this BCT was activated (BCT code 3.1, general). Thus, it is not clear which support types or associated BCT codes were included (i.e., practical vs. emotional support; 3.2 and 3.3, respectively). It is possible that the interventions described without sufficient detail expected that using a group format would automatically activate social support. Importantly, however, it is clear from BCT 
guidelines that activating social support requires more than simply bringing individuals together in groups; social support must be actively facilitated by the intervention process and/or content (Michie et al., 2013). This oversight may represent a critical limitation of existing physical activity interventions designed for women in midlife, and could be addressed with additional attention to facilitating social support in these programs. It is difficult to draw strong conclusions in this vein without additional information. Effectively activating social support may be particularly relevant and powerful for women in midlife, given the cognitive, physiological, and social changes and stressors that women commonly experience during this period of development (Infurna et al., 2020) and their demonstrated utility in other populations of women (e.g., Flannery et al., 2019; Jenkins et al., 2017; Joseph et al., 2019; Perez et al., 2010).

Critically, however, there was limited evidence to suggest that any of the BCTs included in physical activity interventions were tailored specifically for use with women in midlife. This is surprising, given the considerable existing evidence that tailored interventions and intervention components are associated with more favorable physical activity and related behavioral health outcomes than those that are not (Berry et al., 2021; Krebs et al., 2010). Lack of tailoring of behavioral BCTs in general, and self-monitoring and goal setting skills in particular, in physical activity promotion interventions for women in midlife may be a missed opportunity that could be addressed in future research. For example, interventions might specifically address how to set goals, effectively self-monitor, and recruit social support resources while managing work, caregiving, and physical changes such as those that accompany midlife and menopause. Tailoring BCTs for use with women in midlife may increase the perceived acceptability of physical activity promotion interventions for this population and prove helpful in addressing their low physical activity engagement rates (Lee \& Ory, 2013; National Center for Health 
Statistics, 2019). Here too, however, it is difficult to make strong recommendations without additional information about the activation of these BCTs.

\section{Reporting Limitations Associated with Existing Intervention Studies}

Overall, the present review shows that only a few BCTs that are prevalent in physical activity interventions for women in midlife are described in detail, whereas many are referenced with little or no information about their activation. Further, the selected theoretical grounding and associated BCTs (e.g., those that support self-efficacy enhancement through the lens of Social Cognitive Theory) often are described as uniquely matched to the needs of women in midlife. This is particularly true for the inclusion of social support. Indeed, some research has documented lack of support as a barrier to physical activity engagement among women in midlife (e.g., Im et al., 2012), though this (or similar) evidence was not invoked to justify emphasis on activating social support to promote physical activity in this population. In general, very few articles included in this review clearly articulated the alignment between the specific needs of women in midlife, the theories or BCTs selected, and the processes used to activate the particular BCTs in interventions.

One view is that not providing this level of detail is justified, on multiple fronts. First, the primary goal of the articles included in this review was to report on intervention outcomes, and space restrictions in many journals prevent the inclusion of details about both intervention delivery and evaluation. The recent trend of publishing protocol papers may help to address this problem, especially given that many protocols are published with open access. However, this separates relevant details about intervention delivery from indicators of efficacy or effectiveness, both in terms of physical publication space and in terms of timing (as protocol papers often are published much earlier than outcomes). Thus, it can take considerable added effort to get a sense 
of which BCTs are used, with what rationale, and to what effect, slowing down progress toward effective physical activity promotion for women in midlife.

Second, detailed information about intervention delivery often is considered proprietary until (or long after) final-stage dissemination trials are complete, and may never become widely available. It may be prudent to avoid publicizing the details of an intervention until it has undergone thorough testing. As most publications tout the positive outcomes of each intervention, however, it would be useful for researchers to have more information about what, specifically, led to these outcomes. This is consistent with conclusions from prior meta-analyses, which have indicated lack of explicit identification (and measurement) of theoretically informed BCTs that are targeted by physical activity interventions, as well as a lack of information on how intervention content specifically maps onto the chosen theory's purported mechanisms of action (Prestwich et al., 2014). This lack of detail may be particularly problematic for populations such as women in midlife, for whom existing physical activity interventions have generally exhibited limited efficacy (Murray et al., 2017).

As a result, even with acknowledging these realities of publishing behavioral intervention research, overarching impressions of the state of this literature are that it offers little clarity or consensus about how to build effective physical activity interventions for women in midlife, and that there have been few innovations in this field over the past 20 years. With respect to building interventions, the programs were described in too little detail to be replicated and extended in future work by other clinical researchers. Without an understanding of how these interventions activate the intended BCTs, researchers intending to advance the field have to rely on other information, such as their own previous experience (which may be idiosyncratic or inaccurate with respect to existing work). This is particularly problematic for interventions shown to be 
superior to a comparison condition in large-scale trials (e.g., Khare et al., 2012, Scarinci et al., 2014), as these should be prime candidates for ongoing refinement and dissemination. Available literature thus offers little fodder for hypotheses about why certain physical activity interventions may be more effective for women in midlife than others or which BCTs should be retained; this may be one reason for repetition of several BCTs and combinations, rather than expansion with novel approaches.

\section{BCTs that Warrant Additional Attention in Future Work with Women in Midlife}

There are several theories and associated BCTs that are becoming more common in behavioral interventions to promote health behavior change, but have rarely been included in physical activity interventions for women in midlife. For example, mindfulness- and acceptancebased approaches to intervention teach participants to increase present-moment awareness of decision-making, connect their actions to their overarching life values, and tolerate temporary physical or emotional discomfort if actions align with their values (Hayes et al., 2006). In the context of physical activity intervention, physical activity engagement is presented as supportive of participants' values (such as overall health or caregiving for others); any efforts to focus on deliberate decision-making about physical activity and discomfort during physical activity (including boredom or dislike) are considered tolerable in the pursuit of a values-driven life (cf. Forman \& Butryn, 2015). This perspective invokes BCTs such as reframing (BCT code 13.2), self-talk (15.4), and regulating negative emotions (11.2), albeit with specific techniques such as cognitive defusion (i.e., acknowledging thoughts and emotions without acting on them). Interventions that focus on promoting these skills have led to meaningful increases in physical activity among college students (Butryn et al., 2011) and adults with overweight and obesity 
(Butryn et al., 2018; 2021). Yet, mindfulness- and acceptance-based skills were not highlighted (or not described in sufficient detail) in studies included in this review.

Similarly, emerging evidence shows that activating social comparisons of physical activity in the context of digitally supported behavioral interventions is associated with physical activity increases among women (BCT code 6.2; Arigo, 2015; Arigo, Schumacher, Pinkasavage, \& Butryn, 2015). In these interventions, participants have access to each other's real-time physical activity engagement (i.e., totals of steps and minutes of moderate- and vigorousintensity activity), collected via wearable physical activity monitor; totals are ranked from most to least on a leaderboard to induce comparisons between participants. Women in midlife may be particularly responsive to social comparison opportunities, as their daily physical activity behavior changes with fluctuations in naturally occurring comparison activity (Arigo, Mogle, \& Smyth, 2021) and they identify lack of physical activity role models as a barrier to engagement (Vrazel, Saunders, \& Wilcox, 2008). However, social comparison was activated in only one of the articles included in the present review (Butryn et al., 2016). Although a second article (Peterson et al., 2005) described its intervention as based on Social Comparison Theory (Festinger, 1954), the translation of this theory to the intervention components was not clearly delineated.

In contrast, behavioral modeling was referenced in 14 articles (27\%; BCT code 6.1), whereby participants were able to view someone else performing a skill correctly (e.g., an intervention facilitator). Behavioral modeling may involve comparing oneself to the model to limit discrepancies between one's own and the model's behavior; however, modeling often involves comparing to someone perceived as an expert, whereas social comparison focuses on comparing to nonexpert peers (e.g., other intervention participants; Abraham \& Michie, 2008). It 
is not clear whether one is more effective for promoting physical activity among women in midlife, either overall or in certain intervention contexts. Thus, the use of BCTs based on promoting social comparison, mindfulness, and acceptance-based skills, as well as those that incorporate digital supports that can reach women in daily life, represent opportunities for introducing new techniques to physical activity interventions for women in midlife.

\section{Implications for Promoting Physical Activity among Women in Midlife}

The present review also illustrates the acknowledged lack of consensus about how to define "midlife," as well as how to define "physically inactive." Ages that qualified as midlife ranged from 30 to 69, and some studies used menopause status in lieu of an age range (e.g., Gabriel et al., 2011; Asbury et al., 2006; Hollis et al., 2014). Across studies, there also were 8 different thresholds used to indicate physical inactivity. These inconsistencies have been noted in recent work examining midlife health and sedentary lifestyles (Infurna et al., 2020; Tremblay et al., 2017), which raises critical questions about tailored physical activity promotion for women in this life stage: for whom are these interventions currently designed, and could increased consistency in the definitions of key criteria improve intervention development (as well as uptake, efficacy, and effectiveness)?

For instance, women at the ages of 65-69 may have very different physical and psychological needs than women at the ages of 30-35 (Berkman \& Soh, 2017), and barriers to behavior change may look very different for someone already achieving 60 minutes of moderateto-vigorous physical activity per week, relative to someone achieving only 10 (or 0; Powell, Paluch, \& Blair, 2011). Attempting to address these wide ranges of needs in a single intervention program (relative to focusing on a smaller range of needs in more depth) may dilute its efficacy. Further, as many physical activity interventions for this population purport to foster social 
support between women as a BCT, heterogeneity between women may be counterproductive.

Exposure to differing experiences can offer new perspectives, particularly if someone who has been through an experience can provide comfort or advice (cf. Kulik, Mahler, \& Moore, 1996). However, support may be suboptimally effective if women do not see group members as relatable or able to understand their challenges, or may be less beneficial for older women who share their experience (as there may be few opportunities for reciprocation; Carmack Taylor et al., 2007). As noted, greater attention to social support in physical activity interventions for women in midlife could be important for improving their efficacy and effectiveness (see Table 3). Overall, it appears that there is little consistency in the population of interest, which could hinder efforts to address physical inactivity in this group.

\section{Strengths, Limitations, and Additional Future Directions}

To our knowledge, this is the first systematic overview of existing literature on behavioral interventions to increase physical activity among women in midlife. Given that this is an area of considerable interest (as evidenced by the number of relevant publications in the past two decades), the present review should be useful for providing researchers with a synthesis of existing approaches to intervention. This review also used pre-registered methods and relied on consensus across multiple coders to extract relevant information from each article. As we conducted a scoping review, rather than a traditional systematic review or quantitative metaanalysis, we are not able to draw conclusions about the efficacy of existing interventions or the BCTs that are most strongly associated with physical activity increases in this population. This is an important next step for research in this area and will help to advance the field, by identifying the BCTs that should be included in future interventions and those that may be eliminated or modified. This work would be most useful with the inclusion of age range (or other definition of 
midlife) and physical activity inclusion criteria as potential moderators, to determine whether greater participant homogeneity in interventions is associated with better outcomes.

Finally, it is critical that researchers understand not just which BCTs are associated with physical activity increases, but how these BCTs are activated to achieve these outcomes and how they are received by women in midlife. If protocol papers provide a useful outlet for presenting this information, publishing such papers should be an expected step in intervention development and testing. This likely will require ongoing financial resources to support publication (i.e., for open-access article processing costs), and researchers should plan to identify these types of papers in their preparation for intervention work, in addition to identifying papers that report on outcomes. An alternative to publishing a separate protocol paper would be to include more detailed information about an intervention in supplements for outcomes papers; supplemental sections now available for many publications and often appear online only. As there are several potential issues with the current use of supplemental sections, however (see Pop \& Salzburg, 2015), these should be carefully considered and crafted to provide the most relevant information about the intervention. These steps also will help to advance the field by both increasing replicability and limiting time spent merely "reinventing the wheel" of physical activity interventions for women in midlife. 


\section{References}

Abraham, C., \& Michie, S. (2008). A taxonomy of behavior change techniques used in interventions. Health Psychology, 27(3), 379-387. https://psycnet.apa.org/doi/10.1037 /0278-6133.27.3.379

Agomo, H. C., Andresen, P. A., \& Deshmukh, D. (2015). Be wise: Implementing a lifestyle intervention to reduce stroke risk in low-income midlife women. Journal of Neuroscience Nursing, 47(1), 36-43. https://psycnet.apa.org/doi/10.1097/JNN.0000000000000108

Anderson, D., Mizzari, K., Kain, V., \& Webster, J. (2006). The effects of a multimodal intervention trial to promote lifestyle factors associated with the prevention of cardiovascular disease in menopausal and postmenopausal Australian women. Health Care for Women International, 27(3), 238-253. https://doi.org/10.1080/07399330500506543

Anderson, D., Seib, C., \& Rasmussen, L. (2014). Can physical activity prevent physical and cognitive decline in postmenopausal women? A systematic review of the literature.

Maturitas, 79(1), 14-33. https://doi.org/10.1016/j.maturitas.2014.06.010

Arigo, D. (2015). Promoting physical activity among women using wearable technology and online social connectivity: A feasibility study. Health Psychology and Behavioral Medicine, 3(1), 391-409. https://doi.org/10.1080/21642850.2015.1118350

Arigo, D., Brown, M.M., Pasko, K. Ainsworth, M.C., Travers, L., Gupta, A.A., Symons Downs, D., \& Smyth, J.M (2020). Rationale and design of the Women's Health And Daily Experiences project: Protocol for an ecological momentary assessment study to identify real-time predictors of midlife women's physical activity. JMIR Research Protocols, 9(10), e19044. https://doi.org/10.2196/19044 
Arigo, D., Jake-Schoffman, D. E., Wolin, K., Beckjord, E., Hekler, E. B., \& Pagoto, S. L. (2019). The history and future of digital health in the field of behavioral medicine. Journal of Behavioral Medicine, 42(1), 67-83. https://doi.org/10.1007/s10865-018-9966-z

Arigo, D., Mogle, J.A., Brown, M.M., Roberts, S.R., Pasko, K., Butryn, M.L., \& Symons Downs, D. (2020). Differences in accelerometer cut point methods among midlife women with cardiovascular risk markers. Menopause, 27(5), 559-567. https://doi.org/10.1097 /GME.0000000000001498

Arigo, D., Mogle, J. A., \& Smyth, J. M. (2021). Relations between social comparisons and physical activity among women in midlife with elevated risk for cardiovascular disease: An ecological momentary assessment study. Journal of Behavioral Medicine, 44(5), 579-590. https://doi.org/10.1007/s10865-021-00229-7

Arigo, D., Schumacher, L. M., Pinkasavage, E., \& Butryn, M. L. (2015). Addressing barriers to physical activity among women: A feasibility study using social networking-enabled technology. Digital Health, 1,2055207615583564. https://doi.org/10.1177\%2F20552 07615583564

Arksey, H., \& O'Malley, L. (2005). Scoping studies: towards a methodological framework. International Journal of Social Research Methodology, 8(1), 19-32. https://doi.org/10.1080/1364557032000119616

Asbury, E. A., Chandrruangphen, P., \& Collins, P. (2006). The importance of continued exercise participation in quality of life and psychological well-being in previously inactive postmenopausal women: a pilot study. Menopause, 13(4), 561-567. https://doi.org/10.1097 /01.gme.0000196812.96128.e8 
Bandura, A. (1982). Self-efficacy mechanism in human agency. American Psychologist, 37(2), 122-147. https://doi.org/10.1037/0003-066X.37.2.122.

Bandura, A. (1998). Health promotion from the perspective of social cognitive theory. Psychology \& Health, 13(4), 623-649. https://doi.org/10.1080/08870449808407422

Berkman, L. F., \& Soh, Y. (2017). Social determinants of health at older ages: The long arm of early and middle adulthood. Perspectives in Biology and Medicine, 60(4), 595-606. http://doi.org/10.1353/pbm.2017.0045

Berry, R., Kassavou, A., \& Sutton, S. (2021). Does self-monitoring diet and physical activity behaviors using digital technology support adults with obesity or overweight to lose weight? A systematic literature review with meta-analysis. Obesity Reviews, e13306. https://doi.org /10.1111/obr.13306

Blair, S. N. (2009). Physical inactivity: The biggest public health problem of the 21 st century. British journal of sports medicine, 43(1), 1-2. https://bjsm.bmj.com/content/bjsports/43/1/ 1.full.pdf?casa_token=JJhanI0CDygAAAAA:FAQnP2-1Sewshx_1RqNpPJX9K1j5liWVe M8taWjr4K-ZrDeQYZ91qjkCJHX4mWYNHOIo3Pd_pHTV

Butryn, M. L., Arigo, D., Raggio, G. A., Colasanti, M., \& Forman, E. M. (2016). Enhancing physical activity promotion in midlife women with technology-based self-monitoring and social connectivity: A pilot study. Journal of Health Psychology, 21(8), 1548-1555. https: //doi.org/10.1177\%2F1359105314558895

Butryn, M. L., Forman, E., Hoffman, K., Shaw, J., \& Juarascio, A. (2011). A pilot study of acceptance and commitment therapy for promotion of physical activity. Journal of Physical Activity and Health, 8(4), 516-522. https://doi.org/10.1123/jpah.8.4.516 
Butryn, M. L., Godfrey, K. M., Call, C. C., Forman, E. M., Zhang, F., \& Volpe, S. L. (2021). Promotion of physical activity during weight loss maintenance: A randomized controlled trial. Health Psychology, 40(3), 178. https://psycnet.apa.org/doi/10.1037/hea0001043

Butryn, M. L., Kerrigan, S., Arigo, D., Raggio, G., \& Forman, E. M. (2018). Pilot test of an acceptance-based behavioral intervention to promote physical activity during weight loss maintenance. Behavioral Medicine, 44(1), 77-87. https://doi.org/10.1080/08964289.2016. 1170663

Carels, R. A., Darby, L. A., Cacciapaglia, H. M., \& Douglass, O. M. (2004). Reducing cardiovascular risk factors in postmenopausal women through a lifestyle change intervention. Journal of Women's Health, 13(4), 412-426. https://doi.org/10.1089/1540999 04323087105

Carmack Taylor, C. L., Kulik, J., Badr, H., Smith, M., Basen-Engquist, K., Penedo, F., \& Gritz, E. R. (2007). A social comparison theory analysis of group composition and efficacy of cancer support group programs. Social Science \& Medicine, 65(2), 262-273. https://doi.org /10.1016/j.socscimed.2007.03.024

Caspersen, C. J., Pereira, M. A., \& Curran, K. M. (2000). Changes in physical activity patterns in the United States, by sex and cross-sectional age. Medicine \& Science in Sports \& Exercise, 32(9), 1601-1609. https://doi.org/0195-9131/00/3209-1601/0

Conroy, M. B., Sward, K. L., Spadaro, K. C., Tudorascu, D., Karpov, I., Jones, B. L., ... \& Kapoor, W. N. (2015). Effectiveness of a physical activity and weight loss intervention for middle-aged women: healthy bodies, healthy hearts randomized trial. Journal of General Internal Medicine, 30(2), 207-213. https://doi.org/10.1007/s11606-014-3077-5 
Cooke, R., \& Jones, A. (2017). Recruiting adult participants to physical activity intervention studies using sport: a systematic review. BMJ Open Sport \& Exercise Medicine, 3(1). http://dx.doi.org/10.1136/bmjsem-2017-000231

Costanzo, C., Walker, S. N., Yates, B. C., McCabe, B., \& Berg, K. (2006). Physical activity counseling for older women. Western Journal of Nursing Research, 28(7), 786-801. https://doi.org/10.1177\%2F0193945906289495

Cussler, E. C., Teixeira, P. J., Going, S. B., Houtkooper, L. B., Metcalfe, L. L., Blew, R. M., ... \& Lohman, T. G. (2008). Maintenance of weight loss in overweight middle-aged women through the Internet. Obesity, 16(5), 1052-1060. https://doi.org/10.1038/oby.2008.19

Ehlers, D. K., Huberty, J. L., \& de Vreede, G. J. (2015). Can an evidence-based book club intervention delivered via a tablet computer improve physical activity in middle-aged women?. Telemedicine and e-Health, 21(2), 125-131. https://doi.org/10.1089/tmj.2013.0360

Epton, T., Currie, S., \& Armitage, C. J. (2017). Unique effects of setting goals on behavior change: Systematic review and meta-analysis. Journal of Consulting and Clinical Psychology, 85(12), 1182-1198. https://psycnet.apa.org/doi/10.1037/ccp0000260

Festinger, L. (1954). A theory of social comparison processes. Human Relations, 7(2), 117-140. https://doi.org/10.1177\%2F001872675400700202

Flannery, C., Fredrix, M., Olander, E. K., McAuliffe, F. M., Byrne, M., \& Kearney, P. M. (2019). Effectiveness of physical activity interventions for overweight and obesity during pregnancy: A systematic review of the content of behaviour change interventions. The International Journal of Behavioral Nutrition and Physical Activity, 16(1), 1-20. https://doi.org/10.1186/s12966-019-0859-5 
Fitzgibbon, M. L., Stolley, M. R., Schiffer, L., Sanchez-Johnsen, L. A., Wells, A. M., \& Dyer, A. (2005). A combined breast health/weight loss intervention for Black women. Preventive Medicine, 40(4), 373-383. https://doi.org/10.1016/j.ypmed.2004.06.018

Forman, E. M., \& Butryn, M. L. (2015). A new look at the science of weight control: How acceptance and commitment strategies can address the challenge of self-regulation. Appetite, 84, 171-180. https://doi.org/10.1016/j.appet.2014.10.004

Gabriel, K. P., Conroy, M. B., Schmid, K. K., Storti, K. L., High, R. R., Underwood, D. A., ... \& Kuller, L. H. (2011). The impact of weight and fat mass loss and increased physical Activity on physical function in overweight, postmenopausal Women: Results from the WOMAN study. Menopause, 18(7), 759-765. https://dx.doi.org/10.1097\%2Fgme.0b013e31820acdcc

Gardner, B., Wardle, J., Poston, L., \& Croker, H. (2011). Changing diet and physical activity to reduce gestational weight gain: A meta-analysis. Obesity Reviews, 12(7), e602-e620. https://doi.org/10.1111/j.1467-789X.2011.00884.x

Gaston, M. H., Porter, G. K., \& Thomas, V. G. (2007). Prime Time Sister Circles: evaluating a gender-specific, culturally relevant health intervention to decrease major risk factors in midlife African-American women. Journal of the National Medical Association, 99(4), 428-438. https://www.ncbi.nlm.nih.gov/pmc/articles/PMC2569659/

Gebretatyos, H., Amanuel, S., Ghirmai, L., Gebreyohannes, G., \& Tesfamariam, E. H. (2020). Effect of health education on healthy nutrition and physical activity among female teachers aged 40-60 years in Asmara, Eritrea: a quasi experimental study. Journal of Nutrition and Metabolism, 2020, 5721053. https://doi.org/10.1155/2020/5721053

Gilinsky, A. S., Dale, H., Robinson, C., Hughes, A. R., McInnes, R., \& Lavallee, D. (2015). Efficacy of physical activity interventions in post-natal populations: Systematic review, 
meta-analysis and content coding of behaviour change techniques. Health Psychology Review, 9(2), 244-263. https://doi.org/10.1080/17437199.2014.899059

Gill, J. M. R., \& Cooper, A. R. (2008). Physical Activity and Prevention of Type 2 Diabetes Mellitus. Sports Medicine, 38(10), 807-824. https://doi.org/10.2165/00007256-2008381 00-00002

Hayashi, T., Farrell, M. A., Chaput, L. A., Rocha, D. A., \& Hernandez, M. (2010). Lifestyle intervention, behavioral changes, and improvement in cardiovascular risk profiles in the California WISEWOMAN project. Journal of Women's Health, 19(6), 1129-1138. https://doi.org/10.1089/jwh.2009.1631

Hayes, S. C., Luoma, J. B., Bond, F. W., Masuda, A., \& Lillis, J. (2006). Acceptance and commitment therapy: Model, processes and outcomes. Behaviour Research and Therapy, 44(1), 1-25. https://doi.org/10.1016/j.brat.2005.06.006

Hollis, J. L., Williams, L. T., Morgan, P. J., \& Collins, C. E. (2015). The 40-Something Randomised Controlled Trial improved fruit intake and nutrient density of the diet in midage women. Nutrition \& Dietetics, 72(4), 316-326. https://doi.org/10.1111/1747-0 080.12215

Hollis, J. L., Williams, L. T., Young, M. D., Pollard, K. T., Collins, C. E., \& Morgan, P. J. (2014). Compliance to step count and vegetable serve recommendations mediates weight gain prevention in mid-age, premenopausal women. Findings of the 40-Something RCT. Appetite, 83, 33-41. https://doi.org/10.1016/j.appet.2014.07.020

Hu, F. B., Stampfer, M. J., Colditz, G. A., Ascherio, A., Rexrode, K. M., Willett, W. C., \& Manson, J. E. (2000). Physical activity and risk of stroke in women. Journal of the American Medical Association, 283(22), 2961-2967. https://doi.org/10.1001/jama.283 
.22 .2961

Im, E. O., Chang, S. J., Chee, W., \& Chee, E. (2012). Attitudes of women in midlife to webbased interventions for promoting physical activity. Journal of Telemedicine and Telecare, 18(7), 419-422. https://doi.org/10.1258\%2Fjtt.2012.120514

Im, E. O., Stuifbergen, A. K., \& Walker, L. (2010). A situation-specific theory of midlife women's attitudes toward physical activity (MAPA). Nursing Outlook, 58(1), 52-58. https://doi.org/10.1016/j.outlook.2009.07.001

Infurna, F. J., Gerstorf, D., \& Lachman, M. E. (2020). Midlife in the 2020s: Opportunities and challenges. American Psychologist, 75(4), 470-485.http://dx.doi.org/10.1037/amp0000591

Jenkins, F., Jenkins, C., Gregoski, M. J., \& Magwood, G. S. (2017). Interventions promoting physical activity in African American women: An integrative review. Journal of Cardiovascular Nursing, 32(1), 22-29. https://dx.doi.org/10.1097\%2FJCN.0000000 000000298

Joseph, R. P., Ainsworth, B. E., Hollingshead, K., Todd, M., \& Keller, C. (2021). Results of a culturally tailored smartphone-delivered physical activity intervention among midlife African American women: Feasibility trial. JMIR mHealth and uHealth, 9(4), e27383. https://doi.org/10.2196/27383

Joseph, R. P., Royse, K. E., \& Benitez, T. J. (2019). A systematic review of electronic and mobile health (e- and mHealth) physical activity interventions for African American and Hispanic women. Journal of Physical Activity \& Health, 16(3), 230-239. https://doi.org/10 .1123/jpah.2018-0103

Karvinen, S., Jergenson, M. J., Hyvärinen, M., Aukee, P., Tammelin, T., Sipilä, S., ... \& Laakkonen, E. K. (2019). Menopausal status and physical activity are independently 
associated with cardiovascular risk factors of healthy middle-aged women: Cross-sectional and longitudinal evidence. Frontiers in Endocrinology, 10, 589. https://doi.org/10.3389 /fendo.2019.00589

Keyserling, T. C., Hodge, C. D. S., Jilcott, S. B., Johnston, L. F., Garcia, B. A., Gizlice, Z., ... \& Ammerman, A. S. (2008). Randomized trial of a clinic-based, community-supported, lifestyle intervention to improve physical activity and diet: the North Carolina enhanced WISEWOMAN project. Preventive Medicine, 46(6), 499-510. https://doi.org/10.1016 /j.ypmed.2008.02.011

Khare, M. M., Carpenter, R. A., Huber, R., Bates, N. J., Cursio, J. F., Balmer, P. W., Nolen, K. N., Hudson, H., Shippee, S. J., \& Loo, R. K. (2012). Lifestyle intervention and cardiovascular risk reduction in the Illinois WISEWOMAN Program. Journal of Women's Health (2002), 21(3), 294-301. https://doi.org/10.1089/jwh.2011.2926

Kim, Y. (2020). The effects of a physical inactivity-related health risk message intervention on changes in risk perceptions and physical activity in middle-aged women. Journal of Women \& Aging, 32(5), 546-562. https://doi.org/10.1080/08952841.2019.1607678

Kim, Y., \& Kang, S. (2020). Effects of a weight control intervention based on the transtheoretical model on physical activity and psychological variables in middle-aged obese women. Journal of Women \& Aging, 1-13. https://doi.org/10.1080/08952841.2020.1728183

Kim, Y., Lee, Y. M., Cho, M., \& Lee, H. (2019). Effect of a pedometer-based, 24-week walking intervention on depression and acculturative stress among migrant women workers. International Journal of Environmental Research and Public Health, 16(22), 4385. https://doi.org/10.3390/ijerph16224385 
Koniak-Griffin, D., Brecht, M. L., Takayanagi, S., Villegas, J., Melendrez, M., \& Balcázar, H. (2015). A community health worker-led lifestyle behavior intervention for Latina (Hispanic) women: Feasibility and outcomes of a randomized controlled trial. International Journal of Nursing Studies, 52(1), 75-87. https://doi.org/10.1016/j.ijnurstu.2014.09.005

Krebs, P., Prochaska, J. O., \& Rossi, J. S. (2010). A meta-analysis of computer-tailored interventions for health behavior change. Preventive Medicine, 51(3-4), 214-221. https://doi.org/10.1016/j.ypmed.2010.06.004

Kulik, J. A., Mahler, H. I., \& Moore, P. J. (1996). Social comparison and affiliation under threat: Effects on recovery from major surgery. Journal of Personality and Social Psychology, 71(5), 967-979. https://psycnet.apa.org/doi/10.1037/0022-3514.71.5.967

Kuller, L. H., Gabriel, K. K. P., Kinzel, L. S., Underwood, D. A., Conroy, M. B., Chang, Y., ... \& Kriska, A. M. (2012). The Women on the Move Through Activity and Nutrition (WOMAN) study: final 48-month results. Obesity, 20(3), 636-643. https://doi.org/10.1038/oby.2011.80

Lee, W.-C., \& Ory, M. G. (2013). The Engagement in Physical Activity for Middle-Aged and Older Adults with Multiple Chronic Conditions: Findings from a Community Health Assessment. Journal of Aging Research, 2013, e152868. https://doi.org/10.1155/2013 $/ 152868$

Lin, C.-H., Chiang, S.-L., Yates, P., Lee, M.-S., Hung, Y.-J., Tzeng, W.-C., \& Chiang, L.-C. (2015). Moderate physical activity level as a protective factor against metabolic syndrome in middle-aged and older women. Journal of Clinical Nursing, 24(9-10), 1234-1245. https://doi.org/10.1111/jocn.12683 
Long, J. E., Ring, C., Bosch, J. A., Eves, F., Drayson, M. T., Calver, R., ... \& Burns, V. E. (2013). A life-style physical activity intervention and the antibody response to pneumococcal vaccination in women. Psychosomatic Medicine, 75(8), 774-782. https://doi.org/10.1097 /PSY.0b013e3182a0b664

Low, V., Gebhart, B., \& Reich, C. (2015). Effects of a worksite program to improve the cardiovascular health of female health care workers. Journal of Cardiopulmonary Rehabilitation and Prevention, 35(5), 342-347. https://doi.org/10.1097/HCR.0000000 000000116

Ludman, E., Simon, G. E., Ichikawa, L. E., Operskalski, B. H., Arterburn, D., Linde, J. A., ... \& Finch, E. A. (2009). Does depression reduce the effectiveness of behavioral weight loss treatment?. Behavioral Medicine, 35(4), 126-134. https://doi.org/10.1080/08964280903334527

Lynch, B. M., Neilson, H. K., \& Friedenreich, C. M. (2011). Physical activity and breast cancer prevention. Recent Results in Cancer Research, 186, 13-42. https://doi.org/10.1007/978-3 -642-04231-7_2

Matthews, K. A., Abrams, B., Crawford, S., Miles, T., Neer, R., Powell, L. H., \& Wesley, D. (2001). Body mass index in mid-life women: relative influence of menopause, hormone use, and ethnicity. International Journal of Obesity, 25(6), 863-873. https://doi.org/10.1038/sj.ijo .0801618

Matthews, K. A., Crawford, S. L., Chae, C. U., Everson-Rose, S. A., Sowers, M. F., Sternfeld, B., \& Sutton-Tyrrell, K. (2009). Are changes in cardiovascular disease risk factors in midlife women due to chronological aging or to the menopausal transition?. Journal of the American College of Cardiology, 54(25), 2366-2373. https://doi.org/10.1016/j.jacc.2009 
.10 .009

McGuire, A. M., Seib, C., Porter-Steele, J., \& Anderson, D. J. (2019). The association between Web-based or face-to-face lifestyle interventions on the perceived benefits and barriers to exercise in midlife women: Three-Arm Equivalency Study. Journal of Medical Internet Research, 21(8), e10963. https://doi.org/10.2196/10963

Michie, S., Ashford, S., Sniehotta, F. F., Dombrowski, S. U., Bishop, A., \& French, D. P. (2011). A refined taxonomy of behaviour change techniques to help people change their physical activity and healthy eating behaviours: the CALO-RE taxonomy. Psychology \& Health, 26(11), 1479-1498. https://doi.org/10.1080/08870446.2010.540664

Michie, S., Richardson, M., Johnston, M., Abraham, C., Francis, J., Hardeman, W., ... \& Wood, C. E. (2013). The behavior change technique taxonomy (v1) of 93 hierarchically clustered techniques: building an international consensus for the reporting of behavior change interventions. Annals of Behavioral Medicine, 46(1), 81-95. https://doi.org/10.1007/s12160 -013-9486-6

Mirzaei, E., Azar, F. E. F., Ziapour, A., Azadi, N. A., Qorbani, M., Safari, O., \& Mansourian, M. (2020). The Impact of Educational Intervention Based on Theory of Planned Behavior for Promoting Physical Activity Among Middle-Aged Women Referring to Karaj (Iran) Health Centers. International Quarterly of Community Health Education, 41(4), 419-426. https://doi.org/10.1177\%2F0272684X20972849

Moore, S. C., Lee, I.-M., Weiderpass, E., Campbell, P. T., Sampson, J. N., Kitahara, C. M., Keadle, S. K., Arem, H., Berrington de Gonzalez, A., Hartge, P., Adami, H.-O., Blair, C. K., Borch, K. B., Boyd, E., Check, D. P., Fournier, A., Freedman, N. D., Gunter, M., Johannson, M., ... Patel, A. V. (2016). Association of leisure-time physical activity with 
risk of 26 types of cancer in 1.44 million adults. JAMA Internal Medicine, 176(6), 816-825. https://doi.org

/10.1001/jamainternmed.2016.1548

Murray, J. M., Brennan, S. F., French, D. P., Patterson, C. C., Kee, F., \& Hunter, R. F. (2017). Effectiveness of physical activity interventions in achieving behaviour change maintenance in young and middle aged adults: A systematic review and meta-analysis. Social Science \& Medicine, 192, 125-133. https://doi.org/10.1016/j.socscimed.2017.09.021

Napolitano, M. A., Whiteley, J. A., Papandonatos, G., Dutton, G., Farrell, N. C., Albrecht, A., ... \& Marcus, B. H. (2006). Outcomes from the women's wellness project: A communityfocused physical activity trial for women. Preventive Medicine, 43(6), 447-453. https://doi.org/10.1016/j.ypmed.2006.06.011

National Center for Health Statistics. Health, United States, 2019: Table 25. Hyattsville, MD. 2021. Available from: https://www.cdc.gov/nchs/hus/contents2019.htm.

Nazari, L. N., Reisi, M., Tahmasebi, R., \& Javadzade, H. (2020). The effect of web-based educational intervention on physical activity-related energy expenditure among middle-aged women with overweight and obesity: an application of social cognitive theory. Obesity Medicine, 18, 100181. https://doi.org/10.1016/j.obmed.2020.100181

Newman, M. A., Pettee, K. K., Storti, K. L., Richardson, C. R., Kuller, L. H., \& Kriska, A. M. (2009). Monthly variation in physical activity levels in post-menopausal women. Medicine \& Science in Sports \& Exercise, 41(2), 322-327. https://doi.org/10.1249/MSS.0b013e3181 $864 \mathrm{c} 05$

Ortí, E. S., \& Donaghy, M. (2004). A Cognitive-behavioural intervention to increase adherence of adult women exercisers. Advances in Physiotherapy, 6(2), 84-92. https://doi.org/10.1080 
$/ 14038190410020115$

Perez, A., Fleury, J., \& Keller, C. (2010). Review of intervention studies promoting physical activity in Hispanic women. Western Journal of Nursing Research, 32(3), 341-362. https://doi.org/10.1177/0193945909351300

Peterson, J. A., Yates, B. C., Atwood, J. R., \& Hertzog, M. (2005). Effects of a physical activity intervention for women. Western Journal of Nursing Research, 27(1), 93-110. https://doi.org/10.1177/0193945904270912

Pop, M., \& Salzberg, S. L. (2015). Use and mis-use of supplementary material in science publications. BMC Bioinformatics, 16(1), 1-4. https://doi.org/10.1186/s12859-015-0668-z

Powell, K. E., Paluch, A. E., \& Blair, S. N. (2011). Physical activity for health: What kind? How much? How intense? On top of what?. Annual Review of Public Health, 32(1), 349-365. https://doi.org/10.1146/annurev-publhealth-031210-101151

Prestwich, A., Sniehotta, F. F., Whittington, C., Dombrowski, S. U., Rogers, L., \& Michie, S. (2014). Does theory influence the effectiveness of health behavior interventions? Metaanalysis. Health Psychology, 33(5), 465-474. https://doi.org/10.1037/a0032853

Ribeiro, M. A., Martins, M. A., \& Carvalho, C. R. (2014). Interventions to increase physical activity in middle-age women at the workplace: a randomized controlled trial. Medicine \& Science in Sports \& Exercise, 46(5), 1008-15. https://doi.org/ 10.1249/MSS.0000000000 000190

Samuel-Hodge, C. D., Garcia, B. A., Johnston, L. F., Gizlice, Z., Ni, A., Cai, J., ... \& Keyserling, T. C. (2013). Translation of a behavioral weight loss intervention for mid-life, low-income women in local health departments. Obesity, 21(9), 1764-1773. https://doi.org/10.1002 /oby.20317 
Samuel-Hodge, C. D., Johnston, L. F., Gizlice, Z., Garcia, B. A., Lindsley, S. C., Bramble, K. P., ... \& Keyserling, T. C. (2009). Randomized trial of a behavioral weight loss intervention for low-income women: the Weight Wise program. Obesity, 17(10), 1891-1899. https://doi.org /10.1038/oby.2009.128

Scarinci, I. C., Moore, A., Wynn-Wallace, T., Cherrington, A., Fouad, M., \& Li, Y. (2014). A community-based, culturally relevant intervention to promote healthy eating and physical activity among middle-aged African American women in rural Alabama: Findings from a group randomized controlled trial. Preventive Medicine, 69, 13-20. https://doi.org/10.1016 /j.ypmed.2014.08.016

Sedlak, C. A., Doheny, M. O., Estok, P. J., \& Zeller, R. A. (2005). Tailored interventions to enhance osteoporosis prevention in women. Orthopaedic Nursing, 24(4), 270-276. https://doi.org/10.1097/00006416-200507000-00007

Shariati, M., Astaneh, H. P., Khedmat, L., \& Khatami, F. (2021). Promoting sustainable physical activity among middle-aged Iranian women: a conceptual model-based interventional study. BMC Women's Health, 21(1), 1-7. https://doi.org/10.1186/s12905-020-01152-w

Sharpe, P. A., Burroughs, E. L., Granner, M. L., Wilcox, S., Hutto, B. E., Bryant, C. A., ... \& Pekuri, L. (2010). Impact of a community-based prevention marketing intervention to promote physical activity among middle-aged women. Health Education \& Behavior, 37(3), 403-423. https://doi.org/10.1177/1090198109341929

Sherifali, D., Nerenberg, K. A., Wilson, S., Semeniuk, K., Ali, M. U., Redman, L. M., \& Adamo, K. B. (2017). The effectiveness of eHealth technologies on weight management in pregnant and postpartum women: Systematic review and meta-analysis. Journal of Medical Internet Research, 19(10), e8006. https://doi.org/10.2196/jmir.8006 
Shirazi, K. K., Wallace, L. M., Niknami, S., Hidarnia, A., Torkaman, G., Gilchrist, M., \& Faghihzadeh, S. (2007). A home-based, transtheoretical change model designed strength training intervention to increase exercise to prevent osteoporosis in Iranian women aged 4065 years: a randomized controlled trial. Health Education Research, 22(3), 305-317. https://doi.org/10.1093/her/cyl067

Silva, M. N., Marques, M. M., \& Teixeira, P. J. (2014). Testing theory in practice: The example of self-determination theory-based interventions. The European Health Psychologist, 16(5), 171-180. https://ehps.net/ehp/index.php/contents/article/view/ehp.v16.i5.p171/9

Simkin-Silverman, L. R., Wing, R. R., Boraz, M. A., \& Kuller, L. H. (2003). Lifestyle intervention can prevent weight gain during menopause: results from a 5-year randomized clinical trial. Annals of Behavioral Medicine, 26(3), 212-220. https://doi.org/10.1207/S1532 4796ABM2603_06

Taylor, N., Conner, M., \& Lawton, R. (2012). The impact of theory on the effectiveness of worksite physical activity interventions: A meta-analysis and meta-regression. Health Psychology Review, 6(1), 33-73. https://doi.org/10.1080/17437199.2010.533441

Thomas, V. G., Gaston, M. H., Porter, G. K., \& Anderson, A. (2016). Prime time sister Circles® II: evaluating a culturally relevant intervention to decrease psychological and physical risk factors for chronic disease in mid-life African American women. Journal of the National Medical Association, 108(1), 6-18. https://doi.org/10.1016/j.jnma.2015.12.001

Tovar, M., Walker, J. L., \& Rew, L. (2018). Factors associated with physical Activity in Latina women: A systematic review. Western Journal of Nursing Research, 40(2), 270-297. https://doi.org/10.1177/0193945916681004 
Tremblay, M. S., Aubert, S., Barnes, J. D., Saunders, T. J., Carson, V., Latimer-Cheung, A. E., ... \& Chinapaw, M. J. (2017). Sedentary behavior research network (SBRN)-terminology consensus project process and outcome. International Journal of Behavioral Nutrition and Physical Activity, 14(1), 1-17. https://doi.org/10.1186/s12966-017-0525-8

Tricco, A. C., Lillie, E., Zarin, W., O'Brien, K. K., Colquhoun, H., Levac, D., ... \& Straus, S. E. (2018). PRISMA extension for scoping reviews (PRISMA-ScR): checklist and explanation. Annals of Internal Medicine, 169(7), 467-473. https://doi.org/10.7326/M18-0850

Troiano, R. P., Berrigan, D., Dodd, K. W., Masse, L. C., Tilert, T., \& McDowell, M. (2008). Physical activity in the United States measured by accelerometer. Medicine \& Science in Sports \& Exercise, 40(1), 181. https://doi.org/10.1249/mss.0b013e31815a51b3

Vrazel, J., Saunders, R. P., \& Wilcox, S. (2008). An overview and proposed framework of social-environmental influences on the physical-activity behavior of women. American Journal of Health Promotion, 23(1), 2-12. https://doi.org/10.4278/ajhp.06070999

Waters, L. A., Galichet, B., Owen, N., \& Eakin, E. (2011). Who participates in physical activity intervention trials?. Journal of Physical Activity and Health, 8(1), 85-103. https://doi.org/10.1123/jpah.8.1.85

Watson, S. L., Weeks, B. K., Weis, L. J., Harding, A. T., Horan, S. A., \& Beck, B. R. (2018). High-intensity resistance and impact training improves bone mineral density and physical function in postmenopausal women with osteopenia and osteoporosis: The LIFTMOR Randomized Controlled Trial. Journal of Bone and Mineral Research, 33(2), 211-220. https://doi.org/10.1002/jbmr.3659

Webb, T., Joseph, J., Yardley, L., \& Michie, S. (2010). Using the internet to promote health behavior change: A systematic review and meta-analysis of the impact of theoretical basis, 
use of behavior change techniques, and mode of delivery on efficacy. Journal of Medical Internet Research, 12(1), e1376. https://doi.org/10.2196/jmir.1376

White, B. M., Rochell, J. K., \& Warren, J. R. (2020). Promoting cardiovascular health for African American women: An integrative review of interventions. Journal of Women's Health, 29(7), 952-970. https://doi.org/10.1089/jwh.2018.7580

Wills, T. A. (1985). Supportive functions of interpersonal relationships. In Social Support and Health. (pp. 61-82). Academic Press. https://psycnet.apa.org/record/1985-97489-004.

Wilbur, J., Chandler, P., Miller, A. M., Davis, G. C., Aaronson, L. S., \& Mayo, K. (2001). Measuring adherence to a women's walking program. Western Journal of Nursing Research, 23(1), 8-32. https://doi.org/10.1177/01939450122044934

Wilbur, J., McDevitt, J. H., Wang, E., Dancy, B. L., Miller, A. M., Briller, J., ... \& Lee, H. (2008). Outcomes of a home-based walking program for African-American women. American Journal of Health Promotion, 22(5), 307-317. https://doi.org/10.4278/ajhp.22.5.307

Wilbur, J., Miller, A. M., Buchholz, S. W., Fogg, L. F., Braun, L. T., Halloway, S., \& Schoeny, M. E. (2017). African-American women's long-term maintenance of physical activity following a randomized controlled trial. American Journal of Health Behavior, 41(4), 484496. https://doi.org/10.5993/AJHB.41.4.13

Wilbur, J., Miller, A. M., Fogg, L., McDevitt, J., Castro, C. M., Schoeny, M. E., ... \& Dancy, B. L. (2016). Randomized clinical trial of the women's lifestyle physical activity program for African-American women: 24-and 48-week outcomes. American Journal of Health Promotion, 30(5), 335-345. https://doi.org/10.1177/0890117116646342 
Wilbur, J., Vassalo, A., Chandler, P., McDevitt, J., \& Miller, A. M. (2005). Midlife women's adherence to home-based walking during maintenance. Nursing Research, 54(1), 33-40. https://doi.org/10.1097/00006199-200501000-00005

Wildman, R. P., Schott, L. L., Brockwell, S., Kuller, L. H., \& Sutton-Tyrrell, K. (2004). A dietary and exercise intervention slows menopause-associated progression of subclinical atherosclerosis as measured by intima-media thickness of the carotid arteries. Journal of the American College of Cardiology, 44(3), 579-585. https://doi.org/10.1016/j.jacc.2004.03.078

Xi, S., Mao, L., Chen, X., \& Bai, W. (2017). Effect of health education combining diet and exercise supervision in Chinese women with perimenopausal symptoms: a randomized controlled trial. Climacteric, 20(2), 151-156.

https://doi.org/10.1080/13697137.2017.1281903

Zenk, S. N., Wilbur, J., Wang, E., McDevitt, J., Oh, A., Block, R., ... \& Savar, N. (2009). Neighborhood environment and adherence to a walking intervention in African American women. Health Education \& Behavior, 36(1), 167-181. https://doi.org/10.1177/1090198108321249 
Table 1. Descriptive information for each article describing a physical activity intervention for women in midlife $(k=51)$.

\begin{tabular}{|c|c|c|c|c|c|c|c|}
\hline $\begin{array}{c}\text { Authors and } \\
\text { Year }\end{array}$ & Sample Size & Sample Characteristics & $\begin{array}{l}\text { Primary or } \\
\text { Secondary } \\
\text { Outcomes }\end{array}$ & $\begin{array}{c}\text { Length of } \\
\text { Active } \\
\text { Intervention }\end{array}$ & Format(s) & $\begin{array}{c}\text { Control or } \\
\text { Comparison } \\
\text { Condition } \\
\text { (Yes/No) } \\
\end{array}$ & $\begin{array}{l}\text { Delivery } \\
\text { Modality or } \\
\text { Modalities }\end{array}$ \\
\hline $\begin{array}{l}\text { Agomo et al. } \\
(2015)\end{array}$ & 20 & $\begin{array}{l}\text { Women } 40-64 \text { years old, at or } \\
\text { below } 250 \% \text { of the federal } \\
\text { poverty level, uninsured or } \\
\text { underinsured }\end{array}$ & Primary & 4 weeks & Group & No & In person \\
\hline $\begin{array}{l}\text { Anderson et al. } \\
(2006)\end{array}$ & 90 & $\begin{array}{l}\text { Women } 45-60 \text { year old, from } \\
\text { high/low socio-economic and } \\
\text { rural/metropolitan areas }\end{array}$ & Primary & 12 weeks & Individual & Yes & $\begin{array}{l}\text { Hybrid (in person } \\
\text { and web) }\end{array}$ \\
\hline $\begin{array}{l}\text { Asbury et al. } \\
(2006)\end{array}$ & 18 & $\begin{array}{l}\text { Women 50-65 years old, healthy, } \\
\text { postmenopausal (absence of } \\
\text { menstruation for at least } 1 \mathrm{y})\end{array}$ & Primary & 6 weeks & Individual & Yes & In person \\
\hline $\begin{array}{l}\text { Butryn et al. } \\
(2016)\end{array}$ & 26 & $\begin{array}{l}\text { Women } 40-65 \text { years old, }<150 \\
\text { minutes of MVPA per week, with } \\
\text { internet access }\end{array}$ & Primary & 6 months & Group & No & $\begin{array}{l}\text { Hybrid (in person } \\
\text { and web) }\end{array}$ \\
\hline $\begin{array}{l}\text { Carels et al. } \\
(2004)\end{array}$ & 44 & $\begin{array}{l}\text { Women who were } \\
\text { postmenopausal (no menstruation } \\
\text { for at least } 12 \text { months), obese } \\
\text { (BMI } 30+\mathrm{kg} / \mathrm{m} 2 \text { ), sedentary (not } \\
\text { participating in a program of } \\
\text { physical conditioning two or } \\
\text { more times per week for at least } \\
20 \text { minutes per session, } \\
\text { nonsmokers, no significant } \\
\text { medical history }\end{array}$ & Secondary & 6 months & Group & Yes & In person \\
\hline $\begin{array}{l}\text { Conroy et al. } \\
(2015)\end{array}$ & 98 & $\begin{array}{l}\text { Women } 45-65 \text { years old, } \\
\text { BMI }>25,<60 \text { minutes of } \\
\text { PA/week, patient in primary care } \\
\text { clinic }\end{array}$ & Primary & 12 weeks & Group & Yes & In person \\
\hline $\begin{array}{l}\text { Costanzo et al. } \\
(2006)\end{array}$ & 46 & $\begin{array}{l}\text { Women 50-65 years old, } \\
\text { readiness for physical activity } \\
\text { (Physical Activity Readiness } \\
\text { Questionnaire or written } \\
\text { clearance from a physician) }\end{array}$ & Primary & 12 weeks & Individual & Yes & In person \\
\hline
\end{tabular}


Table 1. Descriptive information for each article describing a physical activity intervention for women in midlife $(k=51)$.

\begin{tabular}{|c|c|c|c|c|c|c|c|}
\hline $\begin{array}{l}\text { Authors and } \\
\text { Year }\end{array}$ & Sample Size & Sample Characteristics & $\begin{array}{l}\text { Primary or } \\
\text { Secondary } \\
\text { Outcomes }\end{array}$ & $\begin{array}{c}\text { Length of } \\
\text { Active } \\
\text { Intervention }\end{array}$ & Format(s) & $\begin{array}{l}\text { Control or } \\
\text { Comparison } \\
\text { Condition } \\
(\text { Yes/No) }\end{array}$ & $\begin{array}{c}\text { Delivery } \\
\text { Modality or } \\
\text { Modalities }\end{array}$ \\
\hline $\begin{array}{l}\text { Cussler et al. } \\
(2008)\end{array}$ & 135 & $\begin{array}{l}\text { Women } 40-55 \text { years old, BMI } 25- \\
38 \mathrm{~kg} / \mathrm{m} 2 \text {, perimenopausal (no } \\
\text { definition provided) }\end{array}$ & Secondary & 16 months & $\begin{array}{l}\text { Group and } \\
\text { individual }\end{array}$ & Yes & $\begin{array}{l}\text { In person, then } \\
\text { web (for } \\
\text { maintenance) }\end{array}$ \\
\hline $\begin{array}{l}\text { Ehlers et al. } \\
(2015)\end{array}$ & 20 & $\begin{array}{l}\text { Women 30-64 years old, not } \\
\text { meeting PA guidelines }\end{array}$ & Primary & 12 weeks & $\begin{array}{l}\text { Group and } \\
\text { individual }\end{array}$ & Yes & $\begin{array}{l}\text { in person or web } \\
\text { (depended on } \\
\text { condition) }\end{array}$ \\
\hline $\begin{array}{l}\text { Fitzgibbon et al. } \\
(2005)\end{array}$ & 64 & $\begin{array}{l}\text { Women } 35-65 \text { years old, BMI }>25 \\
\mathrm{~kg} / \mathrm{m} 2 \text {, self-identification as } \\
\text { African American or Black }\end{array}$ & Primary & 20 weeks & Group & Yes & In person \\
\hline $\begin{array}{l}\text { Gabriel et al. } \\
(2011)\end{array}$ & 508 & $\begin{array}{l}\text { Women } 52-62 \text { years old, } \\
\text { postmenopausal (no definition } \\
\text { provided), BMI } 25-39.9 \mathrm{~kg} / \mathrm{m} 2, \\
\text { waist circumference } \geq 80 \mathrm{~cm}, \\
\text { blood pressure } \leq 140 / 90 \mathrm{mmHg}, \\
\text { low density lipoprotein } \\
\text { cholesterol level } 100-160 \mathrm{mg} / \mathrm{dL}\end{array}$ & Secondary & 36 months & Group & Yes & In person \\
\hline $\begin{array}{l}\text { Gaston et al. } \\
(2007)\end{array}$ & 106 & $\begin{array}{l}\text { Women }>35 \text { years old, self- } \\
\text { identification as African } \\
\text { American or Black }\end{array}$ & Primary & 10 weeks & Group & Yes & In person \\
\hline $\begin{array}{l}\text { Gebretatyos et al. } \\
(2020)\end{array}$ & 99 & $\begin{array}{l}\text { Women } 40-60 \text { years old, working } \\
\text { in elementary, junior, or } \\
\text { secondary schools }\end{array}$ & Primary & 3 months & Group & No & In person \\
\hline $\begin{array}{l}\text { Hayashi et al. } \\
(2010)\end{array}$ & 645 & $\begin{array}{l}\text { Women } 40-64 \text { years old, }<200 \% \\
\text { of the federal poverty level, } \\
\text { under- or uninsured }\end{array}$ & Primary & 6 months & Individual & Yes & In person \\
\hline $\begin{array}{l}\text { Hollis et al. } \\
\text { (2014) }\end{array}$ & 54 & $\begin{array}{l}\text { Women } 44-50 \text { years old, non- } \\
\text { obese (BMI<30 kg/m2), pre- } \\
\text { menopausal, healthy }\end{array}$ & Secondary & 12 months & Group & Yes & $\begin{array}{l}\text { Hybrid (in } \\
\text { person, mailing, } \\
\text { print materials) }\end{array}$ \\
\hline $\begin{array}{l}\text { Hollis et al. } \\
(2015)\end{array}$ & 54 & $\begin{array}{l}\text { Women } 44-50 \text { years old, } \\
\text { premenopausal (no definition } \\
\text { provided), BMI } 18.5-29.9 \mathrm{~kg} / \mathrm{m} 2\end{array}$ & Secondary & 12 months & Group & Yes & $\begin{array}{l}\text { Hybrid (in person } \\
\text { and written } \\
\text { materials) }\end{array}$ \\
\hline
\end{tabular}


Table 1. Descriptive information for each article describing a physical activity intervention for women in midlife $(k=51)$.

\begin{tabular}{|c|c|c|c|c|c|c|c|}
\hline $\begin{array}{c}\text { Authors and } \\
\text { Year }\end{array}$ & Sample Size & Sample Characteristics & $\begin{array}{l}\text { Primary or } \\
\text { Secondary } \\
\text { Outcomes }\end{array}$ & $\begin{array}{c}\text { Length of } \\
\text { Active } \\
\text { Intervention }\end{array}$ & Format(s) & $\begin{array}{c}\text { Control or } \\
\text { Comparison } \\
\text { Condition } \\
(\text { Yes/No) } \\
\end{array}$ & $\begin{array}{c}\text { Delivery } \\
\text { Modality or } \\
\text { Modalities }\end{array}$ \\
\hline $\begin{array}{l}\text { Keyserling et al. } \\
(2008)\end{array}$ & 236 & $\begin{array}{l}\text { Women } 40-64 \text { years old, } \\
\text { income at or below } 200 \% \text { of the } \\
\text { federal poverty level }\end{array}$ & Primary & 12 months & $\begin{array}{l}\text { Group and } \\
\text { individual }\end{array}$ & Yes & $\begin{array}{l}\text { Hybrid (in } \\
\text { person, phone, } \\
\text { mail, and } \\
\text { electronic } \\
\text { resources) }\end{array}$ \\
\hline $\begin{array}{l}\text { Khare et al. } \\
(2012)\end{array}$ & 833 & $\begin{array}{l}\text { Women } 40-64 \text { years old, } \\
\text { income }<200 \% \text { of the federal } \\
\text { poverty level, under- or } \\
\text { uninsured }\end{array}$ & Primary & 12 weeks & Individual & Yes & $\begin{array}{l}\text { Hybrid (in person } \\
\text { and written } \\
\text { materials) }\end{array}$ \\
\hline $\operatorname{Kim}(2020)$ & 41 & $\begin{array}{l}\text { Women } 45-54 \text { years old, in } \\
\text { perimenopause, menopause, or } \\
\text { postmenopause, sedentary (not } \\
\text { defined) }\end{array}$ & Primary & 16 weeks & Individual & No & In person \\
\hline $\begin{array}{l}\text { Kim \& Kang } \\
(2020)\end{array}$ & 33 & $\begin{array}{l}\text { BMI }>25, \text { not currently dieting, } \\
\text { midlife not defined (sample } \\
\text { mean age=48) }\end{array}$ & Primary & 12 weeks & Individual & No & In person \\
\hline Kim et al. (2019) & 84 & $\begin{array}{l}\text { Women } 40-65 \text { years old, not } \\
\text { engaging in regular exercise, } \\
\text { self-identification as a Korean } \\
\text { migrant worker }\end{array}$ & Primary & 24 weeks & Individual & Yes & Text message \\
\hline $\begin{array}{l}\text { Koniak-Griffin et } \\
\text { al. (2015) }\end{array}$ & 210 & $\begin{array}{l}\text { Women } 35-64 \text { years old, } \\
\text { BMI }>25 \mathrm{~kg} / \mathrm{m} 2 \text {, otherwise } \\
\text { healthy, self-identified as Latina }\end{array}$ & Primary & 6 months & $\begin{array}{l}\text { Group and } \\
\text { individual }\end{array}$ & Yes & $\begin{array}{l}\text { Hybrid (in person } \\
\text { and phone) }\end{array}$ \\
\hline $\begin{array}{l}\text { Kuller et al. } \\
(2012)\end{array}$ & 508 & $\begin{array}{l}\text { Women } 52-62 \text { years old, BMI } \\
25-39.9 \mathrm{~kg} / \mathrm{m} 2, \text { waist } \\
\text { circumference } \geq 80 \mathrm{~cm} \text {, blood } \\
\text { pressure } \leq 140 / 90 \mathrm{mmHg}, \text { low } \\
\text { density lipoprotein cholesterol } \\
\text { level } 100-160 \mathrm{mg} / \mathrm{dL}\end{array}$ & Primary & 48 months & Group & Yes & In person \\
\hline
\end{tabular}


Table 1. Descriptive information for each article describing a physical activity intervention for women in midlife $(k=51)$.

\begin{tabular}{|c|c|c|c|c|c|c|c|}
\hline $\begin{array}{l}\text { Authors and } \\
\text { Year }\end{array}$ & Sample Size & Sample Characteristics & $\begin{array}{l}\text { Primary or } \\
\text { Secondary } \\
\text { Outcomes }\end{array}$ & $\begin{array}{c}\text { Length of } \\
\text { Active } \\
\text { Intervention }\end{array}$ & Format(s) & $\begin{array}{l}\text { Control or } \\
\text { Comparison } \\
\text { Condition } \\
(\text { Yes/No) }\end{array}$ & $\begin{array}{c}\text { Delivery } \\
\text { Modality or } \\
\text { Modalities }\end{array}$ \\
\hline $\begin{array}{l}\text { Long et al. } \\
(2013)\end{array}$ & 89 & $\begin{array}{l}\text { Women } 35-65 \text { years old, } \\
\text { insufficiently active (participated } \\
\text { in } 30 \text { minutes of moderate- } \\
\text { intensity exercise on } 5 \text { days of } \\
\text { the week) }\end{array}$ & Primary & 16 weeks & Individual & Yes & $\begin{array}{l}\text { Hybrid (in } \\
\text { person + phone, } \\
\text { email, or text) }\end{array}$ \\
\hline Low et al. (2015) & 57 & $\begin{array}{l}\text { Women } 40-65 \text { years old, } \geq 1 \text { risk } \\
\text { factors for CVD (overweight, } \\
\text { high stress level, lack of physical } \\
\text { activity, or smoking) }\end{array}$ & Primary & 6 months & $\begin{array}{l}\text { Group and } \\
\text { individual }\end{array}$ & Yes & $\begin{array}{l}\text { Hybrid (in } \\
\text { person, phone, } \\
\text { and email) }\end{array}$ \\
\hline $\begin{array}{l}\text { Ludman et al. } \\
\text { (2010) }\end{array}$ & 190 & $\begin{array}{l}\text { Women } 40-65 \text { years old, self- } \\
\text { reported BMI> } 30 \mathrm{~kg} / \mathrm{m} 2 \text {, current } \\
\text { depressive disorder (PHQ-9) }\end{array}$ & Secondary & 12 months & Group & No & In person \\
\hline $\begin{array}{l}\text { McGuire et al. } \\
(2018)\end{array}$ & 157 & $\begin{array}{l}\text { Women } 40-65 \text { years old } \\
\text { (additional details provided } \\
\text { elsewhere) }\end{array}$ & Secondary & 12 weeks & Individual & Yes & $\begin{array}{l}\text { Hybrid (in } \\
\text { person and web) }\end{array}$ \\
\hline $\begin{array}{l}\text { Mirzaei et al. } \\
(2020)\end{array}$ & 140 & Women $30-50$ years old & Primary & 2 months & Individual & Yes & In person \\
\hline $\begin{array}{l}\text { Napolitano et al. } \\
(2006)\end{array}$ & 280 & $\begin{array}{l}\text { Inactive ( }<90 \text { min of purposeful } \\
\text { moderate-intensity physical } \\
\text { activity per week. e.g., walking } \\
\text { or }<60 \text { min of vigorous intensity } \\
\text { activity, midlife not defined } \\
\text { (sample mean age=47) }\end{array}$ & Primary & 4-6 months & Individual & Yes & $\begin{array}{l}\text { Print materials } \\
\text { sent via mail }\end{array}$ \\
\hline $\begin{array}{l}\text { Nazari et al. } \\
(2020)\end{array}$ & 91 & $\begin{array}{l}\text { Women } 30-59 \text { years old, } \\
\text { BMI }>24.99 \mathrm{~kg} / \mathrm{m} 2 \text {, at least } 12 \\
\text { years of education }\end{array}$ & Primary & 3 months & Individual & Yes & In person \\
\hline $\begin{array}{l}\text { Newman et al. } \\
(2009)\end{array}$ & 318 & $\begin{array}{l}\text { Women } 45-64 \text { years old, } \\
\text { postmenopausal (defined by age), } \\
\text { waist circumference }>80 \mathrm{~cm} \text {, } \\
\text { BMI } 25-39.9 \mathrm{~kg} / \mathrm{m} 2 \text {, low density } \\
\text { lipoprotein level } 100-160 \mathrm{mg} / \mathrm{dL}\end{array}$ & Secondary & 18 months & Group & Yes & In person \\
\hline
\end{tabular}


Table 1. Descriptive information for each article describing a physical activity intervention for women in midlife $(k=51)$.

\begin{tabular}{|c|c|c|c|c|c|c|c|}
\hline $\begin{array}{c}\text { Authors and } \\
\text { Year }\end{array}$ & Sample Size & Sample Characteristics & $\begin{array}{l}\text { Primary or } \\
\text { Secondary } \\
\text { Outcomes }\end{array}$ & $\begin{array}{c}\text { Length of } \\
\text { Active } \\
\text { Intervention }\end{array}$ & Format(s) & $\begin{array}{c}\text { Control or } \\
\text { Comparison } \\
\text { Condition } \\
(\text { Yes/No) } \\
\end{array}$ & $\begin{array}{c}\text { Delivery } \\
\text { Modality or } \\
\text { Modalities }\end{array}$ \\
\hline $\begin{array}{l}\text { Orti \& Donaghy } \\
(2004)\end{array}$ & 27 & $\begin{array}{l}\text { Women } 49-69 \text { years old, } \\
\text { sedentary (fewer than } 3 \text { sessions } \\
\text { of } 20 \text { min per week of exercise), } \\
\text { normal bone mineral density or } \\
\text { osteopenia, rural residence }\end{array}$ & Primary & 4 weeks & $\begin{array}{l}\text { Group and } \\
\text { individual }\end{array}$ & Yes & In person \\
\hline $\begin{array}{l}\text { Peterson et al. } \\
(2005)\end{array}$ & 42 & $\begin{array}{l}\text { Women } 35-65 \text { years old, } \\
\text { currently inactive }(<30 \text { minutes } \\
\text { of moderate-intensity activity } \\
\text { daily) }\end{array}$ & Primary & 12 weeks & $\begin{array}{l}\text { Group and } \\
\text { individual }\end{array}$ & Yes & $\begin{array}{l}\text { in person or } \\
\text { phone (depended } \\
\text { on condition) }\end{array}$ \\
\hline $\begin{array}{l}\text { Ribeiro et al. } \\
(2014)\end{array}$ & 195 & $\begin{array}{l}\text { Physically inactive }(<30 \text { min of } \\
\text { PA in leisure time }), \text { BMI }<40 \\
\mathrm{~kg} / \mathrm{m} 2 \text {, healthy, midlife not } \\
\text { defined (sample of women } 40- \\
50 \text { years old) }\end{array}$ & Primary & 3 months & $\begin{array}{l}\text { Group or } \\
\text { individual } \\
\text { (depended } \\
\text { on } \\
\text { condition) }\end{array}$ & Yes & in person \\
\hline $\begin{array}{l}\text { Samuel-Hodge et } \\
\text { al. (2009) }\end{array}$ & 143 & $\begin{array}{l}\text { Women } 40-64 \text { years old, } \\
\text { income } \leq 200 \% \text { of the federal } \\
\text { poverty level, uninsured or } \\
\text { under-insured, BMI } 25-45 \\
\mathrm{~kg} / \mathrm{m} 2\end{array}$ & Primary & 16 weeks & $\begin{array}{l}\text { Group or } \\
\text { individual } \\
\text { (depended } \\
\text { on } \\
\text { condition) }\end{array}$ & Yes & $\begin{array}{l}\text { In person or print } \\
\text { (control) }\end{array}$ \\
\hline $\begin{array}{l}\text { Samuel-Hodge et } \\
\text { al. (2013) }\end{array}$ & 126 & $\begin{array}{l}\text { Women } 40-64 \text { years old, } \\
\text { income } \leq 200 \% \text { of the federal } \\
\text { poverty level, BMI } 25-45 \mathrm{~kg} / \mathrm{m} 3\end{array}$ & Primary & 16 weeks & Group & Yes & In person \\
\hline $\begin{array}{l}\text { Scarinci et al. } \\
(2014)\end{array}$ & 309 & $\begin{array}{l}\text { Women } 45-65 \text { years old, self- } \\
\text { identification as African } \\
\text { American }\end{array}$ & Primary & 5 weeks & $\begin{array}{l}\text { Group and } \\
\text { individual }\end{array}$ & Yes & $\begin{array}{l}\text { Hybrid (in person } \\
\text { and phone) }\end{array}$ \\
\hline $\begin{array}{l}\text { Sedlak et al. } \\
(2005)\end{array}$ & 124 & $\begin{array}{l}\text { Women } 50-65 \text { years old, } \\
\text { postmenopausal (no menstrual } \\
\text { cycle in the past } 12 \text { months) }\end{array}$ & Primary & $\begin{array}{l}\text { Self- } \\
\text { administered }\end{array}$ & $\begin{array}{l}\text { Print } \\
\text { materials via } \\
\text { mail }\end{array}$ & Yes & Phone and mail \\
\hline $\begin{array}{l}\text { Shariati et al. } \\
\text { (2021) }\end{array}$ & 80 & $\begin{array}{l}\text { Women } 30-59 \text { years old, } \\
\text { inactive ( }<90 \text { min mod-intensity } \\
\text { PA/week), healthy }\end{array}$ & Primary & 3 months & individual & Yes & $\begin{array}{l}\text { Hybrid (in person } \\
\text { and virtual } \\
\text { meetings) }\end{array}$ \\
\hline
\end{tabular}


Table 1. Descriptive information for each article describing a physical activity intervention for women in midlife $(k=51)$.

\begin{tabular}{|c|c|c|c|c|c|c|c|}
\hline $\begin{array}{c}\text { Authors and } \\
\text { Year }\end{array}$ & Sample Size & Sample Characteristics & $\begin{array}{l}\text { Primary or } \\
\text { Secondary } \\
\text { Outcomes }\end{array}$ & $\begin{array}{c}\text { Length of } \\
\text { Active } \\
\text { Intervention }\end{array}$ & Format(s) & $\begin{array}{l}\text { Control or } \\
\text { Comparison } \\
\text { Condition } \\
(\text { Yes/No) }\end{array}$ & $\begin{array}{c}\text { Delivery } \\
\text { Modality or } \\
\text { Modalities }\end{array}$ \\
\hline $\begin{array}{l}\text { Sharpe et al. } \\
(2010)\end{array}$ & 217 & $\begin{array}{l}\text { Women } 35-54 \text { years old, } \\
\text { insufficiently active ( }<30 \\
\text { minutes of moderate-intensity } \\
\text { activity on } 5 \text { days per week or } \\
<20 \text { minutes per day of } \\
\text { vigorous- intensity activity on } 3 \\
\text { days per week) }\end{array}$ & Primary & 24 weeks & $\begin{array}{l}\text { Group and } \\
\text { individual }\end{array}$ & Yes & $\begin{array}{l}\text { in person, phone, } \\
\text { emailed and print } \\
\text { mailed materials }\end{array}$ \\
\hline $\begin{array}{l}\text { Shirazi et al. } \\
(2007)\end{array}$ & 116 & $\begin{array}{l}\text { Women } 40-65 \text { years old, at least } \\
\text { 5th grade education }\end{array}$ & Secondary & 12 weeks & $\begin{array}{l}\text { Group and } \\
\text { individual }\end{array}$ & Yes & In person \\
\hline $\begin{array}{l}\text { Simkin- } \\
\text { Silverman et al. } \\
(2003)\end{array}$ & 509 & $\begin{array}{l}\text { Women } 44-50 \text { years old, } \\
\text { premenopausal, not taking } \\
\text { hormone replacement therapy, } \\
\text { BMI } 20-34 \mathrm{~kg} / \mathrm{m} 2 \text {, fasting total } \\
\text { cholesterol } 140-260 \mathrm{mg} / \mathrm{dl} \text {, } \\
\text { fasting low density lipoproteins } \\
80-160 \mathrm{mg} / \mathrm{dl} \text {, fasting glucose } \\
\text { level }<140 \mathrm{mg} / \mathrm{dl} \text {, diastolic } \\
\text { blood pressure }<95 \mathrm{~mm} \mathrm{Hg}\end{array}$ & Secondary & 54 months & $\begin{array}{l}\text { Group (all), } \\
\text { individual } \\
\text { (subset) }\end{array}$ & Yes & In person \\
\hline $\begin{array}{l}\text { Thomas et al. } \\
\text { (2016) }\end{array}$ & 922 & $\begin{array}{l}\text { Self-identification as African- } \\
\text { American, midlife not defined } \\
\text { (sample mean age }=55)\end{array}$ & Primary & 12 weeks & Group & Yes & In person \\
\hline $\begin{array}{l}\text { Wilbur et al. } \\
\text { (2001) }\end{array}$ & 156 & $\begin{array}{l}\text { Women } 45-65 \text { years old, } \\
\text { healthy, employed, self- } \\
\text { identification as African } \\
\text { American or Caucasian, } \\
\text { sedentary (not participating in } \\
\text { either physical conditioning or a } \\
\text { sport for } 20 \text { minutes or more per } \\
\text { session, two or more times per } \\
\text { week during the preceding } 6 \\
\text { months) }\end{array}$ & Primary & 24 weeks & Individual & No & In person \\
\hline
\end{tabular}


Table 1. Descriptive information for each article describing a physical activity intervention for women in midlife $(k=51)$.

\begin{tabular}{|c|c|c|c|c|c|c|c|}
\hline $\begin{array}{c}\text { Authors and } \\
\text { Year }\end{array}$ & Sample Size & Sample Characteristics & $\begin{array}{l}\text { Primary or } \\
\text { Secondary } \\
\text { Outcomes }\end{array}$ & $\begin{array}{c}\text { Length of } \\
\text { Active } \\
\text { Intervention }\end{array}$ & Format(s) & $\begin{array}{l}\text { Control or } \\
\text { Comparison } \\
\text { Condition } \\
\text { (Yes/No) }\end{array}$ & $\begin{array}{c}\text { Delivery } \\
\text { Modality or } \\
\text { Modalities }\end{array}$ \\
\hline $\begin{array}{l}\text { Wilbur et al. } \\
(2005)\end{array}$ & 90 & $\begin{array}{l}\text { Women } 45-65 \text { years old, } \\
\text { healthy, employed, self- } \\
\text { identification as African } \\
\text { American or Caucasian, } \\
\text { sedentary (not participating in } \\
\text { either physical conditioning or a } \\
\text { sport for } 20 \text { minutes or more per } \\
\text { session, two or more times per } \\
\text { week during the preceding } 6 \\
\text { months) }\end{array}$ & Primary & 6 months & Individual & No & In person \\
\hline $\begin{array}{l}\text { Wilbur et al. } \\
(2008)\end{array}$ & 281 & $\begin{array}{l}\text { Women } 45-65 \text { years old, } \\
\text { healthy, employed, self- } \\
\text { identification as African } \\
\text { American, sedentary (not } \\
\text { participating in either physical } \\
\text { conditioning or a sport for } 20 \\
\text { minutes or more per session, } \\
\text { two or more times per week } \\
\text { during the preceding } 6 \text { months) }\end{array}$ & Primary & 48 weeks & $\begin{array}{l}\text { Group and } \\
\text { individual }\end{array}$ & Yes & $\begin{array}{l}\text { Hybrid (in person } \\
\text { and phone) }\end{array}$ \\
\hline $\begin{array}{l}\text { Wilbur et al. } \\
(2016)\end{array}$ & 288 & $\begin{array}{l}\text { Women } 45-65 \text { years old, self- } \\
\text { identification as African } \\
\text { American }\end{array}$ & Primary & 48 weeks & $\begin{array}{l}\text { Group and } \\
\text { individual }\end{array}$ & No & $\begin{array}{l}\text { Hybrid (in person } \\
\text { and phone) }\end{array}$ \\
\hline $\begin{array}{l}\text { Wilbur et al. } \\
(2017)\end{array}$ & 288 & $\begin{array}{l}\text { Women } 45-65 \text { years old, } \\
\text { healthy, employed, self- } \\
\text { identification as African } \\
\text { American, sedentary (not } \\
\text { participating in either physical } \\
\text { conditioning or a sport for } 20 \\
\text { minutes or more per session, } \\
\text { two or more times per week } \\
\text { during the preceding } 6 \text { months) }\end{array}$ & Secondary & 24 weeks & $\begin{array}{l}\text { Group and } \\
\text { individual }\end{array}$ & Yes & $\begin{array}{l}\text { Hybrid (in person } \\
\text { and phone) }\end{array}$ \\
\hline
\end{tabular}


Table 1. Descriptive information for each article describing a physical activity intervention for women in midlife $(k=51)$.

\begin{tabular}{|c|c|c|c|c|c|c|c|}
\hline $\begin{array}{c}\text { Authors and } \\
\text { Year }\end{array}$ & Sample Size & Sample Characteristics & $\begin{array}{l}\text { Primary or } \\
\text { Secondary } \\
\text { Outcomes }\end{array}$ & $\begin{array}{c}\text { Length of } \\
\text { Active } \\
\text { Intervention }\end{array}$ & Format(s) & $\begin{array}{c}\text { Control or } \\
\text { Comparison } \\
\text { Condition } \\
(\text { Yes/No }) \\
\end{array}$ & $\begin{array}{c}\text { Delivery } \\
\text { Modality or } \\
\text { Modalities }\end{array}$ \\
\hline $\begin{array}{l}\text { Wildman et al. } \\
\text { (2004) }\end{array}$ & 353 & $\begin{array}{l}\text { Women } 44-50 \text { years old, } \\
\text { premenopausal ( }<3 \text { months of } \\
\text { amenorrhea in the preceding } 6 \\
\text { months), high-normal ranges of } \\
\text { diastolic BP, BMI, fasting } \\
\text { glucose, and cholesterol levels }\end{array}$ & Secondary & 20 weeks & $\begin{array}{l}\text { Group and } \\
\text { individual }\end{array}$ & Yes & In person \\
\hline Xi et al. (2017) & 55 & $\begin{array}{l}\text { Women } 40-55 \text { years old, mild to } \\
\text { moderate perimenopausal } \\
\text { syndrome, Kupperman } \\
\text { Menopause Index (KMI) score } \\
15-35\end{array}$ & Primary & 12 weeks & Individual & Yes & $\begin{array}{l}\text { Hybrid (in } \\
\text { person, phone, } \\
\text { and text) }\end{array}$ \\
\hline $\begin{array}{l}\text { Zenk et al. } \\
(2009)\end{array}$ & 252 & $\begin{array}{l}\text { Women ages } 40-65 \text {, sedentary } \\
\text { (no participation in regular } \\
\text { moderate or vigorous exercise } \\
\text { for } 30 \text { minutes two or more } \\
\text { times a week in the preceding } 6 \\
\text { months), self-identification as } \\
\text { African-American, urban or } \\
\text { suburban residence, no signs of } \\
\text { CVD }\end{array}$ & Secondary & 12 months & Individual & Yes & $\begin{array}{l}\text { Hybrid (in person } \\
\text { and phone) }\end{array}$ \\
\hline
\end{tabular}

Note: $\mathrm{PA}=$ physical activity $; \mathrm{BMI}=$ body mass index. 
Table 2. Theories, behavior change techniques, and methods of activating behavior change techniques in physical activity interventions for women in midlife $(k=51)$.

\begin{tabular}{|c|c|c|c|c|c|c|c|c|c|}
\hline $\begin{array}{l}\text { Authors } \\
\text { and Year }\end{array}$ & $\begin{array}{l}\text { Theoretical } \\
\text { Grounding }\end{array}$ & $\begin{array}{c}\text { Goal } \\
\text { Setting } \\
(1.1,1.3)\end{array}$ & $\begin{array}{c}\text { Self- } \\
\text { Monitoring } \\
(2.3,2.4)\end{array}$ & $\begin{array}{c}\text { Feedback } \\
(2.2)\end{array}$ & $\begin{array}{l}\text { Planning/ } \\
\text { Problem- } \\
\text { Solving } \\
(1.2,1.4)\end{array}$ & $\begin{array}{c}\text { Social Support } \\
(\mathbf{3 . 1}, \mathbf{3 . 2}, \mathbf{3 . 3})\end{array}$ & $\begin{array}{c}\text { Social } \\
\text { Comparison } \\
(6.2)\end{array}$ & $\begin{array}{c}\text { Behavioral } \\
\text { Modeling } \\
(6.1)\end{array}$ & $\begin{array}{l}\text { Other } \\
\text { BCTs }\end{array}$ \\
\hline $\begin{array}{l}\text { Agomo et } \\
\text { al. (2015) }\end{array}$ & $\begin{array}{l}\text { Social } \\
\text { Cognitive } \\
\text { Theory }\end{array}$ & $\begin{array}{l}\text { Topic of } \\
\text { discussion } \\
\text { and } \\
\text { activities } \\
\text { during group } \\
\text { sessions }\end{array}$ & N/A & N/A & $\begin{array}{l}\text { Planning for } \\
\text { achieving small } \\
\text { behavior } \\
\text { changes during } \\
\text { group } \\
\text { discussions }\end{array}$ & $\begin{array}{l}\text { Discussion topic } \\
\text { in group sessions }\end{array}$ & N/A & N/A & N/A \\
\hline $\begin{array}{l}\text { Anderson } \\
\text { et al. } \\
(2006)\end{array}$ & $\begin{array}{l}\text { Bandura's } \\
\text { Self- } \\
\text { Efficacy } \\
\text { model } \\
\text { (Bandura, } \\
1977 \text { ) }\end{array}$ & $\begin{array}{l}\text { Individual } \\
\text { goal-setting } \\
\text { session with } \\
\text { nurse }\end{array}$ & Paper log & N/A & $\begin{array}{l}\begin{array}{l}\text { Planning } \\
\text { (received }\end{array} \\
\text { weekly } \\
\text { exercise } \\
\text { planner in } \\
\text { written } \\
\text { materials) }\end{array}$ & $\begin{array}{l}\text { Noted that } \\
\text { support was } \\
\text { available from } \\
\text { staff but no } \\
\text { detail provided }\end{array}$ & N/A & N/A & N/A \\
\hline $\begin{array}{l}\text { Asbury et } \\
\text { al. (2006) }\end{array}$ & $\begin{array}{l}\text { Not } \\
\text { identified }\end{array}$ & N/A & $\begin{array}{l}\text { Heart rate } \\
\text { monitor, } \\
\text { paper log }\end{array}$ & N/A & & N/A & N/A & N/A & N/A \\
\hline $\begin{array}{l}\text { Butryn et } \\
\text { al. }(2016)\end{array}$ & $\begin{array}{l}\text { Not } \\
\text { identified }\end{array}$ & $\begin{array}{l}\text { Topic of } \\
\text { discussion } \\
\text { and } \\
\text { activities } \\
\text { during group } \\
\text { sessions }\end{array}$ & Fitbit Flex & $\begin{array}{l}\text { Intervention } \\
\text { leaders } \\
\text { provided } \\
\text { feedback on } \\
\text { progress }\end{array}$ & $\begin{array}{l}\text { Planning in } \\
\text { group } \\
\text { discussions and } \\
\text { activities }\end{array}$ & $\begin{array}{l}\text { Facilitation of } \\
\text { support (e.g., } \\
\text { sharing feedback } \\
\text { and tips) in } \\
\text { group session, } \\
\text { posts to } \\
\text { community } \\
\text { board between } \\
\text { sessions via } \\
\text { Fitbit platform }\end{array}$ & $\begin{array}{l}\text { Data sharing } \\
\text { between } \\
\text { group } \\
\text { members } \\
\text { with } \\
\text { leaderboard } \\
\text { visible }\end{array}$ & N/A & $\begin{array}{l}\text { Stimulus } \\
\text { control in } \\
\text { group } \\
\text { discussions } \\
\text { and } \\
\text { activities } \\
(12.3)\end{array}$ \\
\hline
\end{tabular}


Table 2. Theories, behavior change techniques, and methods of activating behavior change techniques in physical activity interventions for women in midlife $(k=51)$.

\begin{tabular}{|c|c|c|c|c|c|c|c|c|c|}
\hline $\begin{array}{l}\text { Authors } \\
\text { and Year }\end{array}$ & $\begin{array}{l}\text { Theoretical } \\
\text { Grounding }\end{array}$ & $\begin{array}{c}\text { Goal Setting } \\
(1.1,1.3)\end{array}$ & $\begin{array}{c}\text { Self- } \\
\text { Monitoring } \\
(2.3,2.4)\end{array}$ & $\begin{array}{c}\text { Feedback } \\
(2.2)\end{array}$ & $\begin{array}{c}\text { Planning/ } \\
\text { Problem- } \\
\text { Solving } \\
(1.2,1.4)\end{array}$ & $\begin{array}{c}\text { Social } \\
\text { Support } \\
(3.1,3.2,3.3)\end{array}$ & $\begin{array}{c}\text { Social } \\
\text { Comparison } \\
(6.2)\end{array}$ & $\begin{array}{c}\text { Behavioral } \\
\text { Modeling } \\
(6.1)\end{array}$ & $\begin{array}{l}\text { Other } \\
\text { BCTs }\end{array}$ \\
\hline $\begin{array}{l}\text { Carels et } \\
\text { al. (2004) }\end{array}$ & $\begin{array}{l}\text { Baumeister's } \\
\text { Self-Control } \\
\text { Theory }\end{array}$ & $\begin{array}{l}\text { Topic of } \\
\text { discussion and } \\
\text { activities } \\
\text { during group } \\
\text { sessions }\end{array}$ & $\begin{array}{l}\text { Caltrac } \\
\text { accelerometer } \\
\text { and paper log }\end{array}$ & N/A & N/A & $\begin{array}{l}\text { Noted } \\
\text { emphasis on } \\
\text { relationships } \\
\text { but no detail } \\
\text { provided }\end{array}$ & N/A & N/A & N/A \\
\hline $\begin{array}{l}\text { Conroy et } \\
\text { al. }(2015)\end{array}$ & $\begin{array}{l}\text { Not } \\
\text { identified }\end{array}$ & N/A & $\begin{array}{l}\text { Pedometer } \\
\text { and paper log }\end{array}$ & N/A & N/A & $\begin{array}{l}\text { Discussion } \\
\text { topic in group } \\
\text { sessions }\end{array}$ & N/A & N/A & N/A \\
\hline $\begin{array}{l}\text { Costanzo } \\
\text { et al. } \\
(2006)\end{array}$ & $\begin{array}{l}\text { Health } \\
\text { Promotion } \\
\text { Model, } \\
\text { Social } \\
\text { Cognitive } \\
\text { Theory }\end{array}$ & $\begin{array}{l}\text { Goals } \\
\text { set/revised } \\
\text { during } \\
\text { behavioral } \\
\text { counseling } \\
\text { sessions: }\end{array}$ & Paper logs & N/A & $\begin{array}{l}\text { Planning and } \\
\text { problem- } \\
\text { solving (to } \\
\text { overcome } \\
\text { PA barriers) } \\
\text { discussed } \\
\text { during } \\
\text { individual } \\
\text { sessions }\end{array}$ & $\begin{array}{l}\text { Discussion } \\
\text { topic in group } \\
\text { sessions }\end{array}$ & N/A & $\begin{array}{l}\text { Muscle- } \\
\text { strengthening } \\
\text { video with } \\
\text { woman } \\
\text { leading } \\
\text { exercises }\end{array}$ & N/A \\
\hline
\end{tabular}


Table 2. Theories, behavior change techniques, and methods of activating behavior change techniques in physical activity interventions for women in midlife $(k=51)$.

\begin{tabular}{|c|c|c|c|c|c|c|c|c|c|}
\hline $\begin{array}{c}\text { Authors } \\
\text { and Year }\end{array}$ & $\begin{array}{l}\text { Theoretical } \\
\text { Grounding }\end{array}$ & $\begin{array}{c}\text { Goal Setting } \\
(1.1,1.3)\end{array}$ & $\begin{array}{c}\text { Self- } \\
\text { Monitoring } \\
(2.3,2.4)\end{array}$ & $\begin{array}{c}\text { Feedback } \\
(2.2)\end{array}$ & $\begin{array}{l}\text { Planning/ } \\
\text { Problem- } \\
\text { Solving } \\
(1.2,1.4)\end{array}$ & $\begin{array}{c}\text { Social } \\
\text { Support } \\
(3.1,3.2, \\
3.3)\end{array}$ & $\begin{array}{c}\text { Social } \\
\text { Comparison } \\
(6.2)\end{array}$ & $\begin{array}{c}\text { Behavioral } \\
\text { Modeling } \\
(6.1)\end{array}$ & Other BCTs \\
\hline $\begin{array}{l}\text { Cussler et } \\
\text { al. (2008) }\end{array}$ & $\begin{array}{l}\text { Not } \\
\text { identified }\end{array}$ & N/A & $\begin{array}{l}\text { Pedometers } \\
\text { and paper or } \\
\text { electronic } \\
\text { logs }\end{array}$ & $\begin{array}{l}\text { Electronic } \\
\text { report of } \\
\text { weight loss } \\
\text { progress } \\
\text { available } \\
\text { during web } \\
\text { phase }\end{array}$ & $\begin{array}{l}\text { Problem- } \\
\text { solving (i.e., } \\
\text { overcoming } \\
\text { barriers to } \\
\text { exercise) } \\
\text { during group } \\
\text { discussions }\end{array}$ & $\begin{array}{l}\text { Participant- } \\
\text { organized } \\
\text { online } \\
\text { support } \\
\text { groups, } \\
\text { monitored by } \\
\text { research staff }\end{array}$ & N/A & N/A & \\
\hline $\begin{array}{l}\text { Ehlers et } \\
\text { al. (2015) }\end{array}$ & $\begin{array}{l}\text { Social } \\
\text { Cognitive } \\
\text { Theory }\end{array}$ & N/A & $\begin{array}{l}\text { Pedometer } \\
\text { and online } \\
\log \end{array}$ & $\begin{array}{l}\text { Instant PA } \\
\text { feedback } \\
\text { (graphs) } \\
\text { from online } \\
\text { pedometer } \\
\text { log }\end{array}$ & $\begin{array}{l}\text { Planning } \\
\text { presented via } \\
\text { workbook and } \\
\text { group } \\
\text { discussions } \\
\text { (in person or } \\
\text { via internet } \\
\text { discussion } \\
\text { board) } \\
\end{array}$ & $\begin{array}{l}\text { Topic in e- } \\
\text { book and } \\
\text { group } \\
\text { discussions }\end{array}$ & N/A & N/A & \\
\hline $\begin{array}{l}\text { Fitzgibbon } \\
\text { et al. } \\
(2005)\end{array}$ & $\begin{array}{l}\text { Social } \\
\text { Cognitive } \\
\text { Theory }\end{array}$ & $\begin{array}{l}\text { Topic of } \\
\text { discussion } \\
\text { and activities } \\
\text { during group } \\
\text { sessions }\end{array}$ & $\begin{array}{l}\text { PA self- } \\
\text { monitoring } \\
\text { referenced } \\
\text { but method } \\
\text { not provided }\end{array}$ & N/A & $\begin{array}{l}\text { Planning in } \\
\text { group } \\
\text { discussions }\end{array}$ & $\begin{array}{l}\text { Discussion } \\
\text { topic in } \\
\text { group } \\
\text { sessions }\end{array}$ & N/A & $\begin{array}{l}\text { Indicated as } \\
\text { included in } \\
\text { group } \\
\text { sessions but } \\
\text { model not } \\
\text { specified }\end{array}$ & $\begin{array}{l}\text { Stimulus } \\
\text { control (12.3) } \\
\text { and } \\
\text { reinforcemen } \\
\text { (many } \\
\text { possible) in } \\
\text { group } \\
\text { discussions }\end{array}$ \\
\hline $\begin{array}{l}\text { Gabriel et } \\
\text { al. (2011) }\end{array}$ & $\begin{array}{l}\text { Not } \\
\text { identified }\end{array}$ & N/A & N/A & N/A & & N/A & N/A & N/A & N/A \\
\hline
\end{tabular}


Table 2. Theories, behavior change techniques, and methods of activating behavior change techniques in physical activity interventions for women in midlife $(k=51)$.

\begin{tabular}{|c|c|c|c|c|c|c|c|c|c|}
\hline $\begin{array}{c}\text { Authors } \\
\text { and Year }\end{array}$ & $\begin{array}{l}\text { Theoretical } \\
\text { Grounding }\end{array}$ & $\begin{array}{c}\text { Goal Setting } \\
(1.1,1.3)\end{array}$ & $\begin{array}{c}\text { Self- } \\
\text { Monitoring } \\
(2.3,2.4)\end{array}$ & $\begin{array}{c}\text { Feedback } \\
(2.2)\end{array}$ & $\begin{array}{c}\text { Planning/ } \\
\text { Problem- } \\
\text { Solving } \\
(1.2,1.4)\end{array}$ & $\begin{array}{c}\text { Social } \\
\text { Support } \\
(\mathbf{3 . 1}, \mathbf{3 . 2}, \mathbf{3 . 3})\end{array}$ & $\begin{array}{c}\text { Social } \\
\text { Comparison } \\
(6.2)\end{array}$ & $\begin{array}{c}\text { Behavioral } \\
\text { Modeling } \\
(\mathbf{6 . 1})\end{array}$ & Other BCTs \\
\hline $\begin{array}{l}\text { Gaston et al. } \\
(2007)\end{array}$ & $\begin{array}{l}\text { Integration of } \\
\text { Social-Cognitive } \\
\text { Theory, the } \\
\text { Transtheoretical } \\
\text { Model, and the } \\
\text { Person-Extended } \\
\text { Family- } \\
\text { Neighborhood } \\
\text { (PEN) Model }\end{array}$ & $\begin{array}{l}\text { Topic of } \\
\text { discussion } \\
\text { and activities } \\
\text { during group } \\
\text { sessions }\end{array}$ & N/A & N/A & N/A & $\begin{array}{l}\text { Noted } \\
\text { support as } \\
\text { part of } \\
\text { rationale no } \\
\text { detail } \\
\text { provided }\end{array}$ & N/A & $\begin{array}{l}\text { Indicated as } \\
\text { included in } \\
\text { the } \\
\text { intervention } \\
\text { but method } \\
\text { and model } \\
\text { not specified }\end{array}$ & $\begin{array}{l}\text { Cognitive } \\
\text { behavioral } \\
\text { strategies } \\
\text { (unspecified) }\end{array}$ \\
\hline $\begin{array}{l}\text { Gebretatyos } \\
\text { et al. }(2020)\end{array}$ & Not identified & N/A & N/A & N/A & N/A & N/A & N/A & N/A & N/A \\
\hline $\begin{array}{l}\text { Hayashi et } \\
\text { al. (2010) }\end{array}$ & $\begin{array}{l}\text { Socioecological } \\
\text { Model }\end{array}$ & $\begin{array}{l}\text { Topic of } \\
\text { discussion } \\
\text { and activities } \\
\text { during } \\
\text { individual } \\
\text { sessions }\end{array}$ & N/A & N/A & N/A & N/A & N/A & N/A & N/A \\
\hline $\begin{array}{l}\text { Hollis et al. } \\
\text { (2014) }\end{array}$ & $\begin{array}{l}\text { Social Cognitive } \\
\text { Theory }\end{array}$ & N/A & $\begin{array}{l}\text { N/A (only } \\
\text { for } \\
\text { assessments) }\end{array}$ & N/A & N/A & N/A & N/A & N/A & N/A \\
\hline $\begin{array}{l}\text { Hollis et al. } \\
\text { (2015) }\end{array}$ & Not identified & N/A & $\begin{array}{l}\text { Pedometer } \\
\text { and paper } \\
\text { log }\end{array}$ & N/A & N/A & N/A & N/A & N/A & $\begin{array}{l}\text { Mailings } \\
\text { included } \\
\text { information } \\
\text { about PA } \\
\text { behavior } \\
\text { change } \\
\text { strategies } \\
\text { (unspecified) }\end{array}$ \\
\hline
\end{tabular}


Table 2. Theories, behavior change techniques, and methods of activating behavior change techniques in physical activity interventions for women in midlife $(k=51)$.

\begin{tabular}{|c|c|c|c|c|c|c|c|c|c|}
\hline $\begin{array}{l}\text { Authors } \\
\text { and Year }\end{array}$ & $\begin{array}{l}\text { Theoretical } \\
\text { Grounding }\end{array}$ & $\begin{array}{c}\text { Goal Setting } \\
(1.1,1.3)\end{array}$ & $\begin{array}{c}\text { Self- } \\
\text { Monitoring } \\
(2.3,2.4)\end{array}$ & $\begin{array}{c}\text { Feedback } \\
(2.2)\end{array}$ & $\begin{array}{c}\text { Planning/ } \\
\text { Problem- } \\
\text { Solving } \\
(1.2,1.4)\end{array}$ & $\begin{array}{c}\text { Social } \\
\text { Support } \\
(3.1,3.2, \\
\text { 3.3) }\end{array}$ & $\begin{array}{c}\text { Social } \\
\text { Comparison } \\
(6.2)\end{array}$ & $\begin{array}{c}\text { Behavioral } \\
\text { Modeling } \\
(6.1)\end{array}$ & Other BCTs \\
\hline $\begin{array}{l}\text { Keyserling } \\
\text { et al. } \\
\text { (2008) }\end{array}$ & Not identified & $\begin{array}{l}\text { Topic of } \\
\text { discussion and } \\
\text { activities } \\
\text { during } \\
\text { individual } \\
\text { sessions }\end{array}$ & Pedometer & $\begin{array}{l}\text { Intervention } \\
\text { leaders } \\
\text { provided } \\
\text { individual } \\
\text { feedback on } \\
\text { progress }\end{array}$ & $\begin{array}{l}\text { Planning } \\
\text { and } \\
\text { problem- } \\
\text { solving in } \\
\text { group and } \\
\text { individual } \\
\text { discussions }\end{array}$ & $\begin{array}{l}\text { Noted that } \\
\text { "sessions } \\
\text { were } \\
\text { designed to } \\
\text { build social } \\
\text { support" } \\
\text { but no } \\
\text { detail } \\
\text { provided }\end{array}$ & N/A & $\begin{array}{l}\text { In-session } \\
\text { guided } \\
\text { exercise } \\
\text { activities } \\
\text { (model not } \\
\text { specified) }\end{array}$ & \\
\hline $\begin{array}{l}\text { Khare et al. } \\
(2012)\end{array}$ & Not identified & N/A & N/A & N/A & & N/A & N/A & N/A & N/A \\
\hline Kim (2020) & Not identified & N/A & N/A & N/A & & N/A & N/A & N/A & N/A \\
\hline $\begin{array}{l}\text { Kim \& } \\
\text { Kang } \\
(2020)\end{array}$ & $\begin{array}{l}\text { Transtheoretical } \\
\text { Model }\end{array}$ & N/A & N/A & N/A & & N/A & N/A & N/A & $\begin{array}{l}\text { Reinforcement } \\
\text { provided by } \\
\text { intervention } \\
\text { leaders (many } \\
\text { possible) }\end{array}$ \\
\hline $\begin{array}{l}\text { Kim et al. } \\
\text { (2019) }\end{array}$ & Not identified & N/A & $\begin{array}{l}\text { Pedometer } \\
\text { and paper } \\
\text { log }\end{array}$ & N/A & & N/A & N/A & N/A & N/A \\
\hline
\end{tabular}


Table 2. Theories, behavior change techniques, and methods of activating behavior change techniques in physical activity interventions for women in midlife $(k=51)$.

\begin{tabular}{|c|c|c|c|c|c|c|c|c|c|}
\hline $\begin{array}{l}\text { Authors } \\
\text { and Year }\end{array}$ & $\begin{array}{l}\text { Theoretical } \\
\text { Grounding }\end{array}$ & $\begin{array}{c}\text { Goal Setting } \\
(1.1,1.3)\end{array}$ & $\begin{array}{c}\text { Self- } \\
\text { Monitoring } \\
(2.3,2.4)\end{array}$ & $\begin{array}{l}\text { Feedback } \\
\quad(2.2)\end{array}$ & $\begin{array}{c}\text { Planning/ } \\
\text { Problem- } \\
\text { Solving } \\
(1.2,1.4) \\
\end{array}$ & $\begin{array}{c}\text { Social } \\
\text { Support } \\
(3.1,3.2, \\
3.3) \\
\end{array}$ & $\begin{array}{c}\text { Social } \\
\text { Comparison } \\
(6.2)\end{array}$ & $\begin{array}{c}\text { Behavioral } \\
\text { Modeling } \\
(6.1)\end{array}$ & Other BCTs \\
\hline $\begin{array}{l}\text { Koniak- } \\
\text { Griffin et } \\
\text { al. (2015) }\end{array}$ & Not identified & $\begin{array}{l}\text { Topic of } \\
\text { discussion } \\
\text { and activities } \\
\text { during } \\
\text { individual } \\
\text { sessions }\end{array}$ & $\begin{array}{l}\text { Pedometer } \\
\text { and paper log }\end{array}$ & N/A & $\begin{array}{l}\text { Problem- } \\
\text { solving } \\
\text { guidance } \\
\text { provided by } \\
\text { intervention } \\
\text { leader }\end{array}$ & $\begin{array}{l}\text { Discussion } \\
\text { topic in } \\
\text { individual } \\
\text { sessions }\end{array}$ & N/A & $\begin{array}{l}\text { Instructor-led } \\
\text { group } \\
\text { exercises, } \\
\text { videos, and } \\
\text { role play } \\
\text { during } \\
\text { intervention } \\
\text { sessions } \\
\end{array}$ & N/A \\
\hline $\begin{array}{l}\text { Kuller et al. } \\
(2012)\end{array}$ & $\begin{array}{l}\text { Cognitive } \\
\text { Behavioral } \\
\text { Theory }\end{array}$ & N/A & N/A & N/A & N/A & N/A & N/A & N/A & N/A \\
\hline $\begin{array}{l}\text { Long et al. } \\
\text { (2013) }\end{array}$ & Not identified & $\begin{array}{l}\text { Topic of } \\
\text { discussion } \\
\text { during } \\
\text { individual } \\
\text { sessions and } \\
\text { workbook } \\
\text { activities }\end{array}$ & Pedometer & N/A & N/A & $\begin{array}{l}\text { Topic in } \\
\text { workbook }\end{array}$ & N/A & N/A & $\begin{array}{l}\text { Intervention } \\
\text { reviewed } \\
\text { barriers to } \\
\text { PA and } \\
\text { relapse } \\
\text { prevention } \\
\text { (in which } \\
\text { components } \\
\text { these } \\
\text { appeared not } \\
\text { clear) }\end{array}$ \\
\hline $\begin{array}{l}\text { Low et al. } \\
(2015)\end{array}$ & Not identified & $\begin{array}{l}\text { Topic of } \\
\text { discussion } \\
\text { and activities } \\
\text { during } \\
\text { individual } \\
\text { sessions } \\
\end{array}$ & N/A & N/A & N/A & $\begin{array}{l}\text { Noted group } \\
\text { walks as a } \\
\text { method of } \\
\text { building } \\
\text { support }\end{array}$ & N/A & N/A & N/A \\
\hline $\begin{array}{l}\text { Ludman et } \\
\text { al. (2010) }\end{array}$ & Not identified & N/A & Paper log & N/A & $\begin{array}{l}\text { Problem- } \\
\text { solving in } \\
\text { group } \\
\text { discussions }\end{array}$ & N/A & N/A & N/A & N/A \\
\hline
\end{tabular}


Table 2. Theories, behavior change techniques, and methods of activating behavior change techniques in physical activity interventions for women in midlife $(k=51)$.

\begin{tabular}{|c|c|c|c|c|c|c|c|c|c|}
\hline $\begin{array}{l}\text { Authors } \\
\text { and Year }\end{array}$ & $\begin{array}{l}\text { Theoretical } \\
\text { Grounding }\end{array}$ & $\begin{array}{c}\text { Goal Setting } \\
(1.1,1.3)\end{array}$ & $\begin{array}{c}\text { Self- } \\
\text { Monitoring } \\
(2.3,2.4)\end{array}$ & Feedback (2.2) & $\begin{array}{c}\text { Planning/ } \\
\text { Problem- } \\
\text { Solving } \\
(1.2,1.4)\end{array}$ & $\begin{array}{c}\text { Social } \\
\text { Support } \\
(3.1,3.2 \text {, } \\
\text { 3.3) }\end{array}$ & $\begin{array}{c}\text { Social } \\
\text { Comparison } \\
(6.2)\end{array}$ & $\begin{array}{c}\text { Behavioral } \\
\text { Modeling } \\
(6.1)\end{array}$ & Other BCTs \\
\hline $\begin{array}{l}\text { McGuire et } \\
\text { al. (2018) }\end{array}$ & $\begin{array}{l}\text { Social } \\
\text { Cognitive } \\
\text { Theory }\end{array}$ & $\begin{array}{l}\text { Topic of } \\
\text { discussion } \\
\text { and activities } \\
\text { during } \\
\text { individual } \\
\text { sessions }\end{array}$ & N/A & N/A & $\begin{array}{l}\text { Weekly } \\
\text { activity } \\
\text { planning, } \\
\text { barriers to } \\
\text { PA reviewed } \\
\text { in print and } \\
\text { electronic } \\
\text { materials, } \\
\text { discussed in } \\
\text { group }\end{array}$ & N/A & N/A & $\begin{array}{l}\text { Photographic } \\
\text { illustrations } \\
\text { of strength } \\
\text { exercises }\end{array}$ & $\mathrm{N} / \mathrm{A}$ \\
\hline $\begin{array}{l}\text { Mirzaei et } \\
\text { al. (2020) }\end{array}$ & $\begin{array}{l}\text { Theory of } \\
\text { Planned } \\
\text { Behavior }\end{array}$ & N/A & N/A & $\begin{array}{l}\text { Received } \\
\text { feedback from } \\
\text { research staff } \\
\text { on PA, needs } \\
\text { and obstacles } \\
\text { to physical } \\
\text { movement, and } \\
\text { solutions } \\
\text { (single session) }\end{array}$ & N/A & N/A & N/A & N/A & N/A \\
\hline $\begin{array}{l}\text { Napolitano } \\
\text { et al. (2006) }\end{array}$ & $\begin{array}{l}\text { Social } \\
\text { Cognitive } \\
\text { Theory, } \\
\text { Trans- } \\
\text { theoretical } \\
\text { Model }\end{array}$ & $\begin{array}{l}\text { Topic of } \\
\text { workbook } \\
\text { activities }\end{array}$ & N/A & $\begin{array}{l}\text { Received } \\
\text { tailored } \\
\text { feedback from } \\
\text { research team } \\
\text { on "self- } \\
\text { efficacy, } \\
\text { barriers, } \\
\text { benefits, social } \\
\text { support, and } \\
\text { goal setting" } \\
\text { (baseline and } \\
\text { months } 1,3,6 \text { ) }\end{array}$ & N/A & $\begin{array}{l}\text { Topic in } \\
\text { workbook }\end{array}$ & N/A & N/A & $\begin{array}{l}\text { Booklet } \\
\text { "matched to } \\
\text { stage of } \\
\text { change" (no } \\
\text { details } \\
\text { provided) }\end{array}$ \\
\hline
\end{tabular}


Table 2. Theories, behavior change techniques, and methods of activating behavior change techniques in physical activity interventions for women in midlife $(k=51)$.

\begin{tabular}{|c|c|c|c|c|c|c|c|c|c|}
\hline $\begin{array}{l}\text { Authors } \\
\text { and Year }\end{array}$ & $\begin{array}{l}\text { Theoretical } \\
\text { Grounding }\end{array}$ & $\begin{array}{c}\text { Goal } \\
\text { Setting } \\
(1.1,1.3)\end{array}$ & $\begin{array}{c}\text { Self- } \\
\text { Monitoring } \\
(2.3,2.4)\end{array}$ & $\begin{array}{c}\text { Feedback } \\
(2.2)\end{array}$ & $\begin{array}{c}\text { Planning/ } \\
\text { Problem- } \\
\text { Solving } \\
(1.2,1.4)\end{array}$ & $\begin{array}{c}\text { Social } \\
\text { Support } \\
(3.1,3.2 \text {, } \\
3.3)\end{array}$ & $\begin{array}{c}\text { Social } \\
\text { Comparison } \\
(6.2)\end{array}$ & $\begin{array}{c}\text { Behavioral } \\
\text { Modeling } \\
(6.1)\end{array}$ & Other BCTs \\
\hline $\begin{array}{l}\text { Nazari et } \\
\text { al. }(2020)\end{array}$ & $\begin{array}{l}\text { Social Cognitive } \\
\text { Theory (SCT) }\end{array}$ & $\begin{array}{l}\text { Topic of } \\
\text { chapter } \\
\text { video }\end{array}$ & N/A & N/A & $\begin{array}{l}\text { Chapter } \\
\text { video } \\
\text { about } \\
\text { planning }\end{array}$ & $\begin{array}{l}\text { Support } \\
\text { persons } \\
\text { invited to } \\
\text { orientation } \\
\text { session and } \\
\text { topic in } \\
\text { video } \\
\text { chapter }\end{array}$ & $\begin{array}{l}\text { Chapter video } \\
\text { showed } \\
\text { testimonial by } \\
\text { peer who lost } \\
17 \mathrm{~kg}\end{array}$ & $\begin{array}{l}\text { Chapter } \\
\text { video } \\
\text { showed an } \\
\text { exercise } \\
\text { session led } \\
\text { by } \\
\text { professional } \\
\text { sports coach } \\
\text { leading } \\
\text { exercises to } \\
\text { be done at } \\
\text { home }\end{array}$ & N/A \\
\hline $\begin{array}{l}\text { Newman } \\
\text { et al. } \\
(2009)\end{array}$ & Not identified & N/A & N/A & N/A & N/A & N/A & N/A & N/A & N/A \\
\hline $\begin{array}{l}\text { Orti \& } \\
\text { Donaghy } \\
(2004)\end{array}$ & $\begin{array}{l}\text { Transtheoretical } \\
\text { Model }\end{array}$ & $\begin{array}{l}\text { Topic of } \\
\text { discussion } \\
\text { and } \\
\text { activities } \\
\text { during } \\
\text { group } \\
\text { sessions }\end{array}$ & $\begin{array}{l}\text { Paper log of } \\
\text { heart rate and } \\
\text { perceived } \\
\text { exertion }\end{array}$ & $\begin{array}{l}\text { Received } \\
\text { feedback from } \\
\text { research staff } \\
\text { on } \\
\text { achievement } \\
\text { of target heart } \\
\text { rate and extent } \\
\text { of } \\
\text { physiological } \\
\text { arousal }\end{array}$ & N/A & N/A & N/A & N/A & $\begin{array}{l}\text { Use of self- } \\
\text { reward to } \\
\text { reinforce PA } \\
\text { and prevent } \\
\text { relapse (10.9) }\end{array}$ \\
\hline
\end{tabular}


Table 2. Theories, behavior change techniques, and methods of activating behavior change techniques in physical activity interventions for women in midlife $(k=51)$.

\begin{tabular}{|c|c|c|c|c|c|c|c|c|c|}
\hline $\begin{array}{c}\text { Authors } \\
\text { and } \\
\text { Year }\end{array}$ & $\begin{array}{l}\text { Theoretical } \\
\text { Grounding }\end{array}$ & $\begin{array}{c}\text { Goal } \\
\text { Setting } \\
(1.1,1.3)\end{array}$ & $\begin{array}{c}\text { Self- } \\
\text { Monitoring } \\
(2.3,2.4)\end{array}$ & $\begin{array}{l}\text { Feedback } \\
\quad(2.2)\end{array}$ & $\begin{array}{l}\text { Planning/ } \\
\text { Problem- } \\
\text { Solving } \\
(1.2,1.4)\end{array}$ & $\begin{array}{c}\text { Social Support } \\
(3.1,3.2,3.3)\end{array}$ & $\begin{array}{c}\text { Social } \\
\text { Comparison } \\
(6.2)\end{array}$ & $\begin{array}{c}\text { Behavioral } \\
\text { Modeling } \\
(6.1)\end{array}$ & Other BCTs \\
\hline $\begin{array}{l}\text { Peterson } \\
\text { et al. } \\
(2005)\end{array}$ & $\begin{array}{l}\text { Adaptation } \\
\text { of Social } \\
\text { Comparison } \\
\text { Theory }\end{array}$ & $\begin{array}{l}\text { Topic of } \\
\text { discussion } \\
\text { and } \\
\text { activities } \\
\text { during } \\
\text { group } \\
\text { sessions }\end{array}$ & $\begin{array}{l}\text { Pedometer } \\
\text { and paper } \\
\text { log }\end{array}$ & $\begin{array}{l}\text { Received } \\
\text { positive } \\
\text { feedback } \\
\text { from } \\
\text { intervention } \\
\text { leader on } \\
\text { fitness/goal } \\
\text { progress } \\
\text { during } \\
\text { weekly } \\
\text { group } \\
\text { sessions }\end{array}$ & N/A & $\begin{array}{l}\text { Sessions designed } \\
\text { to facilitate social } \\
\text { support from the } \\
\text { leader and group } \\
\text { members, } \\
\text { including appraisal } \\
\text { support (PA } \\
\text { recommendations, } \\
\text { safety, CVD } \\
\text { prevention), } \\
\text { belonging support } \\
\text { (groups, spiritual } \\
\text { messages, walking } \\
\text { partners), tangible } \\
\text { support (resources, } \\
\text { facilities), and self- } \\
\text { esteem support } \\
\text { (feedback, self- } \\
\text { monitoring, } \\
\text { rewards) }\end{array}$ & $\begin{array}{l}\text { Noted that } \\
\text { intervention } \\
\text { was based on } \\
\text { social } \\
\text { comparison } \\
\text { theory but no } \\
\text { detail } \\
\text { provided }\end{array}$ & $\begin{array}{l}\text { Noted that } \\
\text { participants } \\
\text { received a } \\
\text { walking } \\
\text { video and } \\
\text { engaged in } \\
\text { group PA, } \\
\text { but } \\
\text { modeling } \\
\text { not } \\
\text { specified }\end{array}$ & N/A \\
\hline $\begin{array}{l}\text { Ribeiro } \\
\text { et al. } \\
(2014)\end{array}$ & $\begin{array}{l}\text { Not } \\
\text { identified }\end{array}$ & N/A & $\begin{array}{l}\text { Pedometer } \\
\text { and paper } \\
\text { log }\end{array}$ & N/A & $\begin{array}{l}\text { Problem- } \\
\text { solving in } \\
\text { group } \\
\text { discussions }\end{array}$ & $\begin{array}{l}\text { Noted group walks } \\
\text { as a method of } \\
\text { building support }\end{array}$ & N/A & N/A & $\begin{array}{l}\text { Use of self- } \\
\text { rewards as } \\
\text { reinforcement } \\
\text { for PA in } \\
\text { group } \\
\text { discussions } \\
(10.9)\end{array}$ \\
\hline
\end{tabular}


Table 2. Theories, behavior change techniques, and methods of activating behavior change techniques in physical activity interventions for women in midlife $(k=51)$.

\begin{tabular}{|c|c|c|c|c|c|c|c|c|c|}
\hline $\begin{array}{c}\text { Authors } \\
\text { and } \\
\text { Year }\end{array}$ & $\begin{array}{l}\text { Theoretical } \\
\text { Grounding }\end{array}$ & $\begin{array}{c}\text { Goal Setting } \\
(1.1,1.3)\end{array}$ & $\begin{array}{c}\text { Self- } \\
\text { Monitoring } \\
(2.3,2.4)\end{array}$ & $\begin{array}{c}\text { Feedback } \\
(2.2)\end{array}$ & $\begin{array}{l}\text { Planning/ } \\
\text { Problem- } \\
\text { Solving } \\
(1.2,1.4)\end{array}$ & $\begin{array}{c}\text { Social } \\
\text { Support } \\
(3.1,3.2, \\
3.3)\end{array}$ & $\begin{array}{c}\text { Social } \\
\text { Comparison } \\
(6.2)\end{array}$ & $\begin{array}{c}\text { Behavioral } \\
\text { Modeling (6.1) }\end{array}$ & $\begin{array}{l}\text { Other } \\
\text { BCTs }\end{array}$ \\
\hline $\begin{array}{l}\text { Samuel- } \\
\text { Hodge et } \\
\text { al. } \\
(2009)\end{array}$ & $\begin{array}{l}\text { Cognitive- } \\
\text { Behavioral } \\
\text { Theory }\end{array}$ & $\begin{array}{l}\text { Topic of } \\
\text { discussion } \\
\text { and activities } \\
\text { during group } \\
\text { or individual } \\
\text { sessions }\end{array}$ & Paper log & $\begin{array}{l}\text { Received } \\
\text { tailored } \\
\text { feedback on } \\
\text { progress } \\
\text { from } \\
\text { research } \\
\text { staff (weeks } \\
6,11,16)\end{array}$ & $\begin{array}{l}\text { Problem- } \\
\text { solving in } \\
\text { group } \\
\text { discussions }\end{array}$ & N/A & N/A & $\begin{array}{l}\text { PA } \\
\text { demonstrations } \\
\text { in group or } \\
\text { individual } \\
\text { sessions } \\
\text { (model not } \\
\text { specified) }\end{array}$ & $\begin{array}{l}\text { Relapse } \\
\text { prevention } \\
\text { in group } \\
\text { discussions } \\
\text { (code not } \\
\text { clear) }\end{array}$ \\
\hline $\begin{array}{l}\text { Samuel- } \\
\text { Hodge et } \\
\text { al. } \\
(2013)\end{array}$ & Not identified & $\begin{array}{l}\text { Topic of } \\
\text { discussion } \\
\text { and activities } \\
\text { during group } \\
\text { sessions }\end{array}$ & Paper log & N/A & N/A & N/A & N/A & $\begin{array}{l}\text { PA } \\
\text { demonstrations } \\
\text { in group } \\
\text { sessions } \\
\text { (model not } \\
\text { specified) }\end{array}$ & N/A \\
\hline $\begin{array}{l}\text { Scarinci } \\
\text { et al. } \\
(2014)\end{array}$ & $\begin{array}{l}\text { Social Cognitive } \\
\text { Theory, } \\
\text { Transtheoretical } \\
\text { Model }\end{array}$ & $\begin{array}{l}\text { Topic of } \\
\text { discussion } \\
\text { and activities } \\
\text { during group } \\
\text { and } \\
\text { individual } \\
\text { sessions }\end{array}$ & N/A & $\begin{array}{l}\text { Intervention } \\
\text { leaders } \\
\text { provided } \\
\text { individual } \\
\text { feedback on } \\
\text { progress }\end{array}$ & $\begin{array}{l}\text { Problem- } \\
\text { solving in } \\
\text { activities and } \\
\text { group and } \\
\text { individual } \\
\text { discussions }\end{array}$ & N/A & N/A & N/A & N/A \\
\hline $\begin{array}{l}\text { Sedlak et } \\
\text { al. } \\
(2005)\end{array}$ & $\begin{array}{l}\text { Revised Health } \\
\text { Belief Model } \\
\text { (RHBM - } \\
\text { Health Belief } \\
\text { Model, Self- } \\
\text { Efficacy) }\end{array}$ & N/A & N/A & N/A & N/A & N/A & N/A & N/A & N/A \\
\hline
\end{tabular}


Table 2. Theories, behavior change techniques, and methods of activating behavior change techniques in physical activity interventions for women in midlife $(k=51)$.

\begin{tabular}{|c|c|c|c|c|c|c|c|c|c|}
\hline $\begin{array}{l}\text { Authors } \\
\text { and Year }\end{array}$ & $\begin{array}{l}\text { Theoretical } \\
\text { Grounding }\end{array}$ & $\begin{array}{c}\text { Goal } \\
\text { Setting } \\
(\mathbf{1 . 1}, \mathbf{1 . 3})\end{array}$ & $\begin{array}{c}\text { Self- } \\
\text { Monitoring } \\
(2.3,2.4)\end{array}$ & $\begin{array}{l}\text { Feedback } \\
\quad(2.2)\end{array}$ & $\begin{array}{l}\text { Planning/ } \\
\text { Problem- } \\
\text { Solving } \\
(1.2,1.4)\end{array}$ & $\begin{array}{c}\text { Social } \\
\text { Support } \\
(3.1,3.2,3.3)\end{array}$ & $\begin{array}{c}\text { Social } \\
\text { Comparison } \\
(6.2)\end{array}$ & $\begin{array}{c}\text { Behavioral } \\
\text { Modeling } \\
(6.1)\end{array}$ & Other BCTs \\
\hline $\begin{array}{l}\text { Shariati et } \\
\text { al. }(2021)\end{array}$ & $\begin{array}{l}\text { Health Belief } \\
\text { Model (HBM) }\end{array}$ & $\begin{array}{l}\text { Topic of } \\
\text { audiobook } \\
\text { component }\end{array}$ & N/A & N/A & N/A & N/A & N/A & $\begin{array}{l}\text { Tutorial } \\
\text { videos } \\
\text { showing } \\
\text { exercise } \\
\text { movements }\end{array}$ & N/A \\
\hline $\begin{array}{l}\text { Sharpe et } \\
\text { al. (2010) }\end{array}$ & $\begin{array}{l}\text { Social } \\
\text { Marketing } \\
\text { Framework, } \\
\text { Social Cognitive } \\
\text { Theory }\end{array}$ & $\begin{array}{l}\text { Topic of } \\
\text { handouts } \\
\text { received } \\
\text { via mail }\end{array}$ & Paper log & N/A & $\begin{array}{l}\text { Problem- } \\
\text { solving, time } \\
\text { management } \\
\text { as topics in } \\
\text { written } \\
\text { materials }\end{array}$ & $\begin{array}{l}\text { Topic in } \\
\text { workbook } \\
\text { and noted } \\
\text { group walks } \\
\text { as a method } \\
\text { of building } \\
\text { support }\end{array}$ & N/A & N/A & $\begin{array}{l}\text { Relapse } \\
\text { prevention as } \\
\text { a topic in } \\
\text { written } \\
\text { materials } \\
\text { (code unclear) }\end{array}$ \\
\hline $\begin{array}{l}\text { Shirazi et } \\
\text { al. (2007) }\end{array}$ & $\begin{array}{l}\text { Transtheoretical } \\
\text { Model (TTM) }\end{array}$ & N/A & N/A & $\begin{array}{l}\text { Intervention } \\
\text { leaders } \\
\text { provided } \\
\text { feedback on } \\
\text { progress }\end{array}$ & N/A & $\begin{array}{l}\text { Discussion } \\
\text { topic in group } \\
\text { and } \\
\text { individual } \\
\text { sessions }\end{array}$ & N/A & N/A & $\begin{array}{l}\text { Counter } \\
\text { conditioning } \\
(14.7), \\
\text { reinforcement } \\
\text { management } \\
\text { (many } \\
\text { possible), and } \\
\text { stimulus } \\
\text { control (12.3) } \\
\text { discussed in } \\
\text { group }\end{array}$ \\
\hline
\end{tabular}


Table 2. Theories, behavior change techniques, and methods of activating behavior change techniques in physical activity interventions for women in midlife $(k=51)$.

\begin{tabular}{|c|c|c|c|c|c|c|c|c|c|}
\hline $\begin{array}{l}\text { Authors } \\
\text { and Year }\end{array}$ & $\begin{array}{l}\text { Theoretical } \\
\text { Grounding }\end{array}$ & $\begin{array}{c}\text { Goal } \\
\text { Setting } \\
(\mathbf{1 . 1}, \mathbf{1 . 3})\end{array}$ & $\begin{array}{c}\text { Self- } \\
\text { Monitoring } \\
(2.3,2.4)\end{array}$ & $\begin{array}{c}\text { Feedback } \\
(2.2)\end{array}$ & $\begin{array}{c}\text { Planning/ } \\
\text { Problem- } \\
\text { Solving } \\
(1.2,1.4)\end{array}$ & $\begin{array}{c}\text { Social } \\
\text { Support } \\
(3.1,3.2,3.3)\end{array}$ & $\begin{array}{c}\text { Social } \\
\text { Comparison } \\
(6.2)\end{array}$ & $\begin{array}{c}\text { Behavioral } \\
\text { Modeling } \\
(6.1)\end{array}$ & Other BCTs \\
\hline $\begin{array}{l}\text { Simkin- } \\
\text { Silverman } \\
\text { et al. } \\
(2003)\end{array}$ & $\begin{array}{l}\text { Cognitive- } \\
\text { Behavioral } \\
\text { Theory }\end{array}$ & N/A & Paper log & $\begin{array}{l}\text { Intervention } \\
\text { leaders } \\
\text { provided } \\
\text { written } \\
\text { feedback on } \\
\text { progress }\end{array}$ & $\mathrm{N} / \mathrm{A}$ & N/A & N/A & N/A & N/A \\
\hline $\begin{array}{l}\text { Thomas } \\
\text { et al. } \\
(2016)\end{array}$ & $\begin{array}{l}\text { Integration of } \\
\text { Social- } \\
\text { Cognitive } \\
\text { Theory, the } \\
\text { Transtheoretical } \\
\text { Model, and the } \\
\text { Person- } \\
\text { Extended } \\
\text { Family- } \\
\text { Neighborhood } \\
\text { (PEN) Model }\end{array}$ & N/A & N/A & N/A & N/A & $\begin{array}{l}\text { Intervention } \\
\text { described as } \\
\text { using a } \\
\text { "supportive } \\
\text { group format" } \\
\text { but no detail } \\
\text { provided }\end{array}$ & N/A & N/A & $\begin{array}{l}\text { Cognitive } \\
\text { behavioral } \\
\text { strategies } \\
\text { (unspecified) }\end{array}$ \\
\hline $\begin{array}{l}\text { Wilbur et } \\
\text { al. (2001) }\end{array}$ & $\begin{array}{l}\text { Transtheoretcial } \\
\text { Model, } \\
\text { Interaction } \\
\text { Model of } \\
\text { Health } \\
\text { Behavior }\end{array}$ & N/A & Paper log & N/A & $\begin{array}{l}\text { Problem- } \\
\text { solving } \\
\text { individual } \\
\text { discussions }\end{array}$ & N/A & N/A & N/A & N/A \\
\hline $\begin{array}{l}\text { Wilbur et } \\
\text { al. (2005) }\end{array}$ & $\begin{array}{l}\text { Interaction } \\
\text { Model of Client } \\
\text { Health } \\
\text { Behavior }\end{array}$ & N/A & Paper log & $\begin{array}{l}\text { Graphs } \\
\text { were } \\
\text { available to } \\
\text { provide } \\
\text { feedback on } \\
\text { intensity of } \\
\text { exercise }\end{array}$ & $\begin{array}{l}\text { Overcoming } \\
\text { barriers in } \\
\text { individual } \\
\text { discussions }\end{array}$ & $\begin{array}{l}\text { Emotional } \\
\text { support and } \\
\text { reinforcement } \\
\text { was given in } \\
\text { the form of } \\
\text { feedback on } \\
\text { progress }\end{array}$ & N/A & N/A & N/A \\
\hline
\end{tabular}


Table 2. Theories, behavior change techniques, and methods of activating behavior change techniques in physical activity interventions for women in midlife $(k=51)$.

\begin{tabular}{|c|c|c|c|c|c|c|c|c|c|}
\hline $\begin{array}{c}\text { Authors } \\
\text { and Year }\end{array}$ & $\begin{array}{l}\text { Theoretical } \\
\text { Grounding }\end{array}$ & $\begin{array}{c}\text { Goal Setting } \\
(1.1,1.3)\end{array}$ & $\begin{array}{c}\text { Self- } \\
\text { Monitoring } \\
(2.3,2.4)\end{array}$ & $\begin{array}{c}\text { Feedback } \\
(2.2)\end{array}$ & $\begin{array}{c}\text { Planning/ } \\
\text { Problem- } \\
\text { Solving } \\
(1.2,1.4)\end{array}$ & $\begin{array}{c}\text { Social } \\
\text { Support } \\
(3.1,3.2,3.3)\end{array}$ & $\begin{array}{c}\text { Social } \\
\text { Comparison } \\
(6.2)\end{array}$ & $\begin{array}{c}\text { Behavioral } \\
\text { Modeling } \\
(6.1)\end{array}$ & Other BCTs \\
\hline $\begin{array}{l}\text { Wilbur et } \\
\text { al. (2008) }\end{array}$ & $\begin{array}{l}\text { Interaction } \\
\text { Model of } \\
\text { Client } \\
\text { Health } \\
\text { Behavior, } \\
\text { Social- } \\
\text { Cognitive } \\
\text { Theory }\end{array}$ & $\begin{array}{l}\text { Topic of } \\
\text { discussion } \\
\text { and activities } \\
\text { during } \\
\text { individual } \\
\text { sessions }\end{array}$ & Paper log & $\begin{array}{l}\text { Intervention } \\
\text { leader } \\
\text { provided } \\
\text { stage- } \\
\text { matched } \\
\text { supportive } \\
\text { feedback, } \\
\text { based on } \\
\text { information } \\
\text { reported to } \\
\text { the } \\
\text { automated } \\
\text { telephone } \\
\text { system }\end{array}$ & $\begin{array}{l}\text { Problem- } \\
\text { solving in } \\
\text { group and } \\
\text { individual } \\
\text { discussions }\end{array}$ & $\begin{array}{l}\text { Noted } \\
\text { emphasis on } \\
\text { facilitating } \\
\text { support } \\
\text { during } \\
\text { intervention } \\
\text { interactions, } \\
\text { no other } \\
\text { details } \\
\text { provided }\end{array}$ & N/A & $\begin{array}{l}\text { Group } \\
\text { sessions } \\
\text { began with } \\
\text { videos } \\
\text { featuring role } \\
\text { models from } \\
\text { the targeted } \\
\text { communities } \\
\text { discussing the } \\
\text { workshop } \\
\text { topic }\end{array}$ & N/A \\
\hline $\begin{array}{l}\text { Wilbur et } \\
\text { al. (2016) }\end{array}$ & $\begin{array}{l}\text { Social } \\
\text { Cognitive } \\
\text { Theory }\end{array}$ & $\begin{array}{l}\text { Topic of } \\
\text { discussion } \\
\text { and activities } \\
\text { during group } \\
\text { sessions }\end{array}$ & $\begin{array}{l}\text { Lifecorder EX } \\
\text { accelerometer } \\
\text { (data entered } \\
\text { into telephone } \\
\text { system) }\end{array}$ & $\begin{array}{l}\text { Lay health } \\
\text { educator } \\
\text { provided } \\
\text { feedback on } \\
\text { steps } \\
\text { reported to } \\
\text { the telephone } \\
\text { system }\end{array}$ & $\begin{array}{l}\text { Problem- } \\
\text { solving and } \\
\text { time } \\
\text { management } \\
\text { in group and } \\
\text { individual } \\
\text { discussions }\end{array}$ & N/A & N/A & $\begin{array}{l}\text { Group } \\
\text { sessions } \\
\text { began with } \\
\text { videos } \\
\text { featuring role } \\
\text { models from } \\
\text { the targeted } \\
\text { communities } \\
\text { discussing the } \\
\text { workshop } \\
\text { topic }\end{array}$ & N/A \\
\hline $\begin{array}{l}\text { Wilbur et } \\
\text { al. (2017) }\end{array}$ & $\begin{array}{l}\text { Social } \\
\text { Cognitive } \\
\text { Theory }\end{array}$ & $\begin{array}{l}\text { Topic of } \\
\text { discussion } \\
\text { and activities } \\
\text { during group } \\
\text { and } \\
\text { individual } \\
\text { sessions }\end{array}$ & $\begin{array}{l}\text { Accelerometer } \\
\text { (unspecified, } \\
\text { data entered } \\
\text { into telephone } \\
\text { system) }\end{array}$ & N/A & $\begin{array}{l}\text { Problem- } \\
\text { solving and } \\
\text { time } \\
\text { management } \\
\text { in group and } \\
\text { individual } \\
\text { discussions }\end{array}$ & $\begin{array}{l}\text { Discussion } \\
\text { topic in } \\
\text { group and } \\
\text { individual } \\
\text { sessions }\end{array}$ & N/A & $\begin{array}{l}\text { Behavioral } \\
\text { rehearsal } \\
\text { through role } \\
\text { modeling } \\
\text { (model not } \\
\text { specified) }\end{array}$ & N/A \\
\hline
\end{tabular}


Table 2. Theories, behavior change techniques, and methods of activating behavior change techniques in physical activity interventions for women in midlife $(k=51)$.

\begin{tabular}{|c|c|c|c|c|c|c|c|c|c|}
\hline $\begin{array}{l}\text { Authors } \\
\text { and Year }\end{array}$ & $\begin{array}{l}\text { Theoretical } \\
\text { Grounding }\end{array}$ & $\begin{array}{c}\text { Goal } \\
\text { Setting } \\
(1.1,1.3)\end{array}$ & $\begin{array}{c}\text { Self- } \\
\text { Monitoring } \\
(2.3,2.4)\end{array}$ & $\begin{array}{c}\text { Feedback } \\
(2.2)\end{array}$ & $\begin{array}{l}\text { Planning/ } \\
\text { Problem- } \\
\text { Solving } \\
(1.2,1.4)\end{array}$ & $\begin{array}{c}\text { Social } \\
\text { Support } \\
(\mathbf{3 . 1}, \mathbf{3 . 2}, \mathbf{3 . 3})\end{array}$ & $\begin{array}{c}\text { Social } \\
\text { Comparison } \\
(6.2)\end{array}$ & $\begin{array}{c}\text { Behavioral } \\
\text { Modeling } \\
(6.1)\end{array}$ & Other BCTs \\
\hline $\begin{array}{l}\text { Wildman } \\
\text { et al. } \\
(2004)\end{array}$ & $\begin{array}{l}\text { Not } \\
\text { identified }\end{array}$ & N/A & N/A & N/A & N/A & N/A & N/A & N/A & N/A \\
\hline $\begin{array}{l}\text { Xi et al. } \\
(2017)\end{array}$ & $\begin{array}{l}\text { Not } \\
\text { identified }\end{array}$ & N/A & N/A & N/A & N/A & & N/A & N/A & N/A \\
\hline $\begin{array}{l}\text { Zenk et al. } \\
(2009)\end{array}$ & $\begin{array}{l}\text { Not } \\
\text { identified }\end{array}$ & N/A & $\begin{array}{l}\text { Heart rate } \\
\text { monitor, } \\
\text { paper log }\end{array}$ & N/A & $\begin{array}{l}\text { Planning in } \\
\text { individual } \\
\text { discussions }\end{array}$ & $\begin{array}{l}\text { Intervention } \\
\text { leaders } \\
\text { provided } \\
\text { tailored, } \\
\text { supportive } \\
\text { telephone } \\
\text { calls }\end{array}$ & N/A & N/A & N/A \\
\hline
\end{tabular}

Note: PA = physical activity, $\mathrm{BCT}$ = behavior change technique; numeric codes refer to Michie and colleagues' (2013) BCT classification system. 
Table 3. Summary of key takeaways from the present review and recommendations for future research on physical activity interventions for women in midlife.

\begin{tabular}{|c|c|}
\hline Observation from Literature Synthesis & Recommendation for Future Work \\
\hline $\begin{array}{l}\text { Use of a wide range of definitions for "midlife" and } \\
\text { "physically inactive/sedentary" }\end{array}$ & $\begin{array}{l}\text { Examine heterogeneity in these areas as moderators of efficacy/effectiveness; include clear rationales } \\
\text { for the definitions and criteria used in each study; test for the benefits of increasing heterogeneity } \\
\text { within studies to maximize the potential power of BCTs such as social support and social comparison } \\
\text { Fieldwide, consider achieving greater consensus about these terms }\end{array}$ \\
\hline $\begin{array}{l}\text { Predominant use of face-to-face intervention only } \\
\text { (with some telephone support) }\end{array}$ & $\begin{array}{l}\text { Explore the adjunctive use of digital components (e.g., online message boards) that can extend } \\
\text { participant contact with intervention material and/or each other (e.g., for social support) }\end{array}$ \\
\hline $\begin{array}{l}\text { Many interventions designed for/included only women } \\
\text { from marginalized groups (e.g., Black/African } \\
\text { American women, women who were uninsured) }\end{array}$ & $\begin{array}{l}\text { Continue to focus on promoting physical activity in marginalized groups using interventions adapted } \\
\text { for their needs }\end{array}$ \\
\hline $\begin{array}{l}\text { Very little detail provided regarding the activation of } \\
\text { BCTs; not always clear which specific BCT was } \\
\text { activated or how this would be replicated in ongoing } \\
\text { intervention work }\end{array}$ & $\begin{array}{l}\text { Include detailed information about the specific BCTs included in the intervention and how these } \\
\text { BCTs are activated (e.g., how specific types of social support were facilitated between group } \\
\text { members); if space is limited, consider the use of supplementary material }\end{array}$ \\
\hline $\begin{array}{l}\text { Little evidence that the theoretical underpinnings or } \\
\text { BCTs were selected for their relevance to women in } \\
\text { midlife, or that BCTs were activated in a way that was } \\
\text { tailored to the specific needs of this population }\end{array}$ & $\begin{array}{l}\text { Specify the population-specific rationale for a theoretical model and BCTs, and increase the use of } \\
\text { BCTs/features that activate BCTs in ways that are tailored to the needs of women in midlife }\end{array}$ \\
\hline $\begin{array}{l}\text { Very little engagement of social comparison processes } \\
\text { or use of third-wave behavioral approaches to } \\
\text { intervention, despite increasing evidence for their } \\
\text { efficacy }\end{array}$ & $\begin{array}{l}\text { Include and test the contributions of social comparison features and techniques informed by } \\
\text { mindfulness- and acceptance-based theories of health behavior change }\end{array}$ \\
\hline
\end{tabular}


Figure 1.
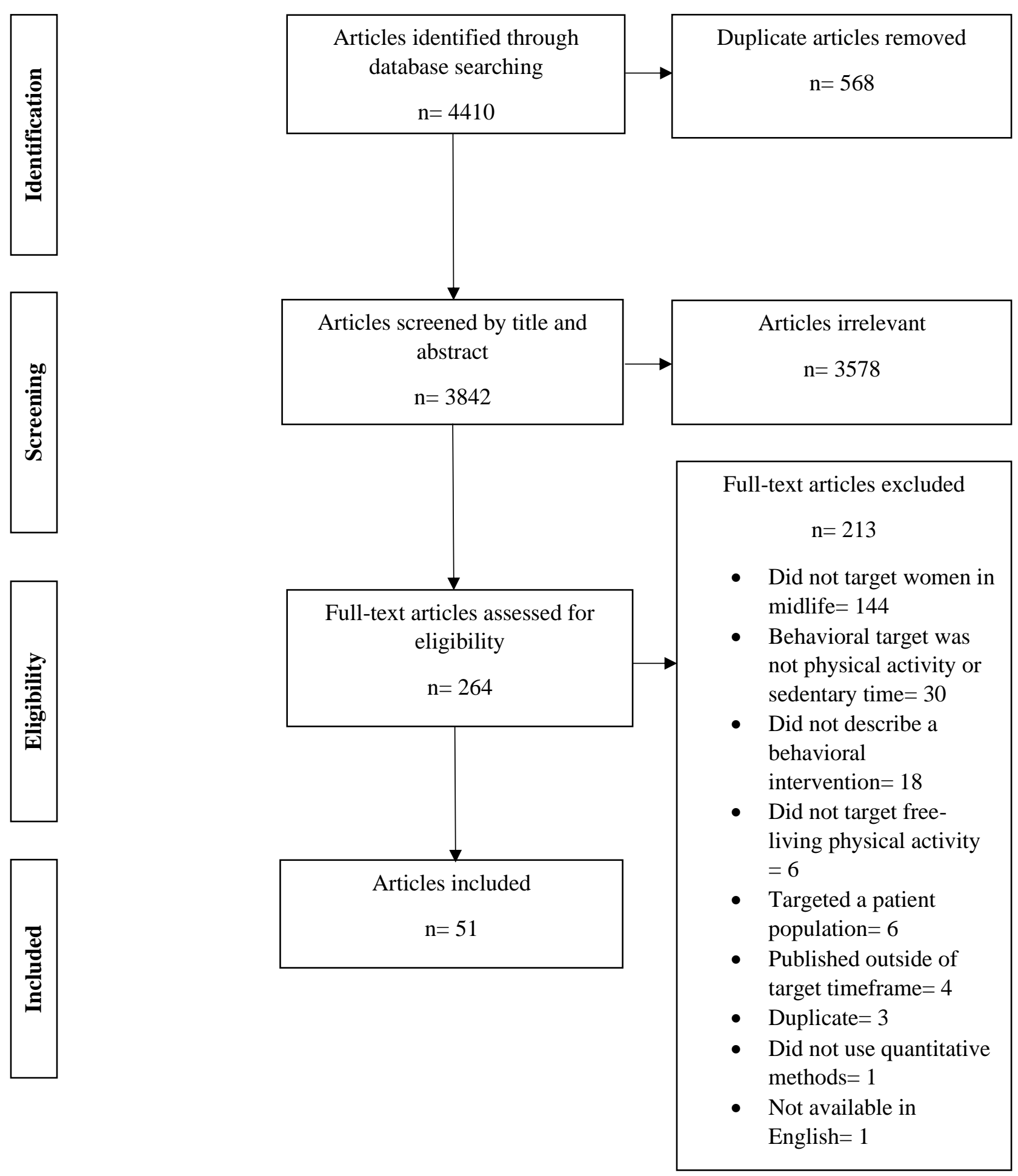
Figure captions.

Figure 1. PRISMA flowchart of selection, sorting, and data extraction. 


\section{Preferred Reporting Items for Systematic reviews and Meta-Analyses extension for Scoping Reviews (PRISMA-ScR) Checklist (Arigo et al., BCT Scoping Review 2021)}

\begin{tabular}{|c|c|c|c|}
\hline SECTION & ITEM & PRISMA-ScR CHECKLIST ITEM & $\begin{array}{l}\text { REPORTED } \\
\text { ON PAGE \# }\end{array}$ \\
\hline \multicolumn{4}{|l|}{ TITLE } \\
\hline Title & 1 & Identify the report as a scoping review. & 1 \\
\hline \multicolumn{4}{|l|}{ ABSTRACT } \\
\hline $\begin{array}{l}\text { Structured } \\
\text { summary }\end{array}$ & 2 & $\begin{array}{l}\text { Provide a structured summary that includes (as } \\
\text { applicable): background, objectives, eligibility criteria, } \\
\text { sources of evidence, charting methods, results, and } \\
\text { conclusions that relate to the review questions and } \\
\text { objectives. }\end{array}$ & $2-3$ \\
\hline \multicolumn{4}{|l|}{ INTRODUCTION } \\
\hline Rationale & 3 & $\begin{array}{l}\text { Describe the rationale for the review in the context of } \\
\text { what is already known. Explain why the review } \\
\text { questions/objectives lend themselves to a scoping } \\
\text { review approach. }\end{array}$ & $4-7$ \\
\hline Objectives & 4 & $\begin{array}{l}\text { Provide an explicit statement of the questions and } \\
\text { objectives being addressed with reference to their key } \\
\text { elements (e.g., population or participants, concepts, } \\
\text { and context) or other relevant key elements used to } \\
\text { conceptualize the review questions and/or objectives. }\end{array}$ & $7-8$ \\
\hline \multicolumn{4}{|l|}{ METHODS } \\
\hline $\begin{array}{l}\text { Protocol and } \\
\text { registration }\end{array}$ & 5 & $\begin{array}{l}\text { Indicate whether a review protocol exists; state if and } \\
\text { where it can be accessed (e.g., a Web address); and if } \\
\text { available, provide registration information, including } \\
\text { the registration number. }\end{array}$ & 8 \\
\hline Eligibility criteria & 6 & $\begin{array}{l}\text { Specify characteristics of the sources of evidence } \\
\text { used as eligibility criteria (e.g., years considered, } \\
\text { language, and publication status), and provide a } \\
\text { rationale. }\end{array}$ & 9 \\
\hline $\begin{array}{l}\text { Information } \\
\text { sources* }^{*}\end{array}$ & 7 & $\begin{array}{l}\text { Describe all information sources in the search (e.g., } \\
\text { databases with dates of coverage and contact with } \\
\text { authors to identify additional sources), as well as the } \\
\text { date the most recent search was executed. }\end{array}$ & $9-10$ \\
\hline Search & 8 & $\begin{array}{l}\text { Present the full electronic search strategy for at least } 1 \\
\text { database, including any limits used, such that it could } \\
\text { be repeated. }\end{array}$ & $9-10$ \\
\hline $\begin{array}{l}\text { Selection of } \\
\text { sources of } \\
\text { evidence† }\end{array}$ & 9 & $\begin{array}{l}\text { State the process for selecting sources of evidence } \\
\text { (i.e., screening and eligibility) included in the scoping } \\
\text { review. }\end{array}$ & 10, Figure 1 \\
\hline $\begin{array}{l}\text { Data charting } \\
\text { process } \ddagger\end{array}$ & 10 & $\begin{array}{l}\text { Describe the methods of charting data from the } \\
\text { included sources of evidence (e.g., calibrated forms or } \\
\text { forms that have been tested by the team before their } \\
\text { use, and whether data charting was done } \\
\text { independently or in duplicate) and any processes for } \\
\text { obtaining and confirming data from investigators. }\end{array}$ & $10-11$ \\
\hline Data items & 11 & $\begin{array}{l}\text { List and define all variables for which data were } \\
\text { sought and any assumptions and simplifications } \\
\text { made. }\end{array}$ & $10-11$ \\
\hline $\begin{array}{l}\text { Critical appraisal of } \\
\text { individual sources } \\
\text { of evidence§ }\end{array}$ & 12 & $\begin{array}{l}\text { If done, provide a rationale for conducting a critical } \\
\text { appraisal of included sources of evidence; describe } \\
\text { the methods used and how this information was used } \\
\text { in any data synthesis (if appropriate). }\end{array}$ & $\mathrm{N} / \mathrm{A}$ \\
\hline
\end{tabular}




\begin{tabular}{|c|c|c|c|}
\hline SECTION & ITEM & PRISMA-ScR CHECKLIST ITEM & $\begin{array}{l}\text { REPORTED } \\
\text { ON PAGE \# }\end{array}$ \\
\hline $\begin{array}{l}\text { Synthesis of } \\
\text { results }\end{array}$ & 13 & $\begin{array}{l}\text { Describe the methods of handling and summarizing } \\
\text { the data that were charted. }\end{array}$ & $\begin{array}{l}11, \text { Tables } 2 \\
\& 3\end{array}$ \\
\hline \multicolumn{4}{|l|}{ RESULTS } \\
\hline $\begin{array}{l}\text { Selection of } \\
\text { sources of } \\
\text { evidence }\end{array}$ & 14 & $\begin{array}{l}\text { Give numbers of sources of evidence screened, } \\
\text { assessed for eligibility, and included in the review, with } \\
\text { reasons for exclusions at each stage, ideally using a } \\
\text { flow diagram. }\end{array}$ & 10, Figure 1 \\
\hline $\begin{array}{l}\text { Characteristics of } \\
\text { sources of } \\
\text { evidence }\end{array}$ & 15 & $\begin{array}{l}\text { For each source of evidence, present characteristics } \\
\text { for which data were charted and provide the citations. }\end{array}$ & 10 \\
\hline $\begin{array}{l}\text { Critical appraisal } \\
\text { within sources of } \\
\text { evidence }\end{array}$ & 16 & $\begin{array}{l}\text { If done, present data on critical appraisal of included } \\
\text { sources of evidence (see item 12). }\end{array}$ & $\mathrm{N} / \mathrm{A}$ \\
\hline $\begin{array}{l}\text { Results of } \\
\text { individual sources } \\
\text { of evidence }\end{array}$ & 17 & $\begin{array}{l}\text { For each included source of evidence, present the } \\
\text { relevant data that were charted that relate to the } \\
\text { review questions and objectives. }\end{array}$ & $11-22$ \\
\hline $\begin{array}{l}\text { Synthesis of } \\
\text { results }\end{array}$ & 18 & $\begin{array}{l}\text { Summarize and/or present the charting results as they } \\
\text { relate to the review questions and objectives. }\end{array}$ & $22-23$ \\
\hline \multicolumn{4}{|l|}{ DISCUSSION } \\
\hline $\begin{array}{l}\text { Summary of } \\
\text { evidence }\end{array}$ & 19 & $\begin{array}{l}\text { Summarize the main results (including an overview of } \\
\text { concepts, themes, and types of evidence available), } \\
\text { link to the review questions and objectives, and } \\
\text { consider the relevance to key groups. }\end{array}$ & $22-32$ \\
\hline Limitations & 20 & Discuss the limitations of the scoping review process. & $31-32$ \\
\hline Conclusions & 21 & $\begin{array}{l}\text { Provide a general interpretation of the results with } \\
\text { respect to the review questions and objectives, as well } \\
\text { as potential implications and/or next steps. }\end{array}$ & $\begin{array}{l}31-32, \text { Table } \\
3\end{array}$ \\
\hline \multicolumn{4}{|l|}{ FUNDING } \\
\hline Funding & 22 & $\begin{array}{l}\text { Describe sources of funding for the included sources } \\
\text { of evidence, as well as sources of funding for the } \\
\text { scoping review. Describe the role of the funders of the } \\
\text { scoping review. }\end{array}$ & $\begin{array}{l}\text { Added in } \\
\text { submission } \\
\text { portal }\end{array}$ \\
\hline \multicolumn{4}{|c|}{$\begin{array}{l}\mathrm{JBI}=\text { Joanna Briggs Institute; PRISMA-ScR = Preferred Reporting Items for Systematic reviews and Meta-Analyses } \\
\text { extension for Scoping Reviews. } \\
\text { * Where sources of evidence (see second footnote) are compiled from, such as bibliographic databases, social media } \\
\text { platforms, and Web sites. } \\
\text { † A more inclusive/heterogeneous term used to account for the different types of evidence or data sources (e.g., } \\
\text { quantitative and/or qualitative research, expert opinion, and policy documents) that may be eligible in a scoping } \\
\text { review as opposed to only studies. This is not to be confused with information sources (see first footnote). } \\
\ddagger \text { The frameworks by Arksey and O'Malley (6) and Levac and colleagues }(7) \text { and the JBI guidance }(4,5) \text { refer to the } \\
\text { process of data extraction in a scoping review as data charting. } \\
\S \text { The process of systematically examining research evidence to assess its validity, results, and relevance before } \\
\text { using it to inform a decision. This term is used for items } 12 \text { and } 19 \text { instead of "risk of bias" (which is more applicable } \\
\text { to systematic reviews of interventions) to include and acknowledge the various sources of evidence that may be used } \\
\text { in a scoping review (e.g., quantitative and/or qualitative research, expert opinion, and policy document). }\end{array}$} \\
\hline
\end{tabular}

From: Tricco AC, Lillie E, Zarin W, O'Brien KK, Colquhoun H, Levac D, et al. PRISMA Extension for Scoping Reviews (PRISMAScR): Checklist and Explanation. Ann Intern Med. 2018;169:467-473. doi: 10.7326/M18-0850. 